\title{
Endocrine aspects of ACE2 regulation: RAAS, steroid hormones and SARS-CoV-2
}

\author{
Morag J Young1,2, Colin D Clyne² and Karen E Chapman ${ }^{3}$ \\ ${ }^{1}$ Baker Heart and Diabetes Institute, Prahran, Australia \\ ${ }^{2}$ Hudson Institute of Medical Research, Clayton, Australia \\ ${ }^{3}$ The University/BHF Centre for Cardiovascular Science, The University of Edinburgh, The Queen's Medical Research Institute, Edinburgh, UK
}

Correspondence should be addressed to M J Young: morag.young@baker.edu.au

\begin{abstract}
Coronavirus disease (COVID-19) is caused by a new strain of coronavirus, the severe acute respiratory syndrome coronavirus 2 or SARS-CoV-2. At the time of writing, SARS-CoV-2 has infected over 5 million people worldwide. A key step in understanding the pathobiology of the SARS-CoV-2 was the identification of -converting enzyme 2 (ACE2) as the receptor for SARS-CoV-2 to gain entry into host cells. ACE2 is an established component of the 'protective arm' of the renin-angiotensin-aldosteronesystem (RAAS) that opposes ACE/angiotensin II (ANG II) pressor and tissue remodelling actions. Identification of ACE 2 as the entry point for SARS-CoV- 2 into cells quickly focused attention on the use of ACE inhibitors (ACEi), angiotensin receptor blockers (ARB) and mineralocorticoid receptor antagonists (MRA) in patients with hypertension and cardiovascular disease given that these pharmacological agents upregulate ACE2 expression in target cells. ACE2 is cleaved from the cells by metalloproteases ADAM10 and ADAM17. Steroid hormone receptors regulate multiple components of the RAAS and may contribute to the observed variation in the incidence of severe COVID-19 between men and women, and in patients with pre-existing endocrine-related disease. Moreover, glucocorticoids play a critical role in the acute and chronic management of inflammatory disease, independent of any effect on RAAS activity. Dexamethasone, a synthetic glucocorticoid, has emerged as a life-saving treatment in severe COVID-19. This review will examine the endocrine mechanisms that control ACE2 and discusses the impact of therapies targeting the RAAS, glucocorticoid and other endocrine systems for their relevance to the impact of SARS-CoV-2 infection and the treatment and recovery from COVID-19-related critical illness.
\end{abstract}

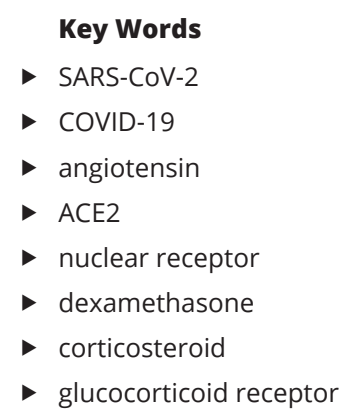

Journal of Endocrinology (2020) 247, R45-R62

\section{Introduction}

The renin-angiotensin aldosterone system (RAAS) operates as a classic endocrine negative feedback loop for the physiological control of extracellular fluid volume and blood pressure via well-described actions of effector hormones on cellular targets. From the first discovery a renal extract with potent pressor effects by Tigerstedt and Bergman (Phillips \& Schmidt-Ott 1999), to the more recent discovery of angiotensin-converting enzyme type 2 (ACE2) (Donoghue et al. 2000, Tipnis et al. 2000), the RAAS has been the subject of numerous studies defining its role in predominantly, but not exclusively, cardiovascular and renal homeostasis and disease. The one kidney 1 clip model 
of hypertension developed by Goldblatt demonstrated the fundamental importance of blood flow to the kidney for the control of blood pressure homeostasis and further supported the concept that factors released from the kidney counter inadequate tissue perfusion (Goldblatt et al. 1934). Angiotensin was discovered soon after, when investigators determined that 'renin' released from the compromised kidney cleaved a peptide in the circulation, enabling pressor effects of renin to be enacted. The other intermediate components of the RAAS were identified in the ensuing years: angiotensinogen, the target of renin enzymatic activity, the existence of two forms of angiotensin, I and II (ANG I and ANG II), and also ACE (Bakhle et al. 1969, Ferreira et al. 1970). The RAAS effector hormone aldosterone (or 'electrocortin') was isolated from renal extracts by Simpson and Tate (Speirs et al. 1954), and a regulatory circuit comprising renin, angiotensin and aldosterone was proposed to regulate sodium homeostasis and blood pressure (Gross \& Lichtlen 1958). The receptor for aldosterone, the mineralocorticoid receptor (MR), was cloned and subsequently identified in the cardiovascular system (cardiomyocytes, vessel wall) (Pearce \& Funder 1987, Funder et al. 1989) as well as many other tissues not necessarily involved in control of blood volume in the kidney.

Research efforts over the subsequent decades has transformed our understanding of the RAAS in the renal and cardiovascular systems. The development of assays and antagonists to control the production (of renin, ACE, aldosterone) and action of the effector hormones ANG II and aldosterone - blocked by ACE inhibitors (ACEi), angiotensin receptor blockers (ARBs) and MR antagonists (MRA) - followed, and these are now a cornerstone for the management of hypertension, cardiovascular and renovascular disease. However, the physiological and pathophysiological actions of the RAAS are far more complex than originally thought. What was first identified as a system for the control of volume and sodium balance now includes wide-ranging effects for ANG II, ACE and aldosterone/MR throughout the body in lung, brain, fat and inflammatory cells among others (Fuller \& Young 2005). Evidence now supports the existence of a local tissue RAAS in many peripheral organs, which is proposed to have autocrine, paracrine, and intracrine effects that differ from the those of the circulating RAAS (Danser 1996, Leung 2004). Of particular relevance to the current review, a vasodilator arm to the RAAS has also been identified that opposes the pressor and remodelling actions of ANG II.
The predominant mediator in the 'protective' arm of the RAAS is ACE2, which is currently receiving considerable attention for its role as the receptor for SARS-CoV-2.

SARS-CoV-2 is most closely related to the SARS-CoV (Serious Acute Respiratory Syndrome or SARS) and MERS (Middle Eastern Respiratory Syndrome) coronaviruses. SARS, but not MERS, also uses ACE2 as the receptor to gain entry to cells. Both SARS-CoV and SARS-CoV-2 cause acute lung injury (ALI) and acute respiratory distress syndrome (ARDS). This hyperinflammatory state, associated with a 'cytokine storm' has similarities to septic shock and critical illness. This leads to organ failure, typically lung, heart or kidney failure, and is fatal in a proportion of infected individuals that develop severe disease. The current SARS-CoV-2 pandemic affecting the human respiratory, cardiovascular, gastrointestinal, among other systems, is a major challenge for public health systems and requires an urgent understanding of COVID-19 pathogenesis, including viral infection and replication within host cells. Although men and women appear to be infected by SARS-CoV-2 at similar rates, the incidence of severe, and often fatal, COVID-19 complications in response to infection is greater for men and for older age groups, especially those with pre-existing cardiovascular disease (Reynolds et al. 2020). Obesity and ethnicity are other significant risk factors for poor outcome. Obesity increases the risk of severe COVID-19 by two- to three-fold, and patients of an African, Asian and minority ethnicity are also more severely affected. Interestingly, although there has been extremely low COVID-19 mortality in children, a rare complication of COVID-19 has emerged in children who has clinical features similar to Kawasaki disease (Verdoni et al. 2020). This pro-inflammatory condition mainly affects the kidney and may be related to the hyperinflammatory state induced in severe COVID-19 in adults.

Many questions have been raised in an effort to understand how underlying cardiovascular disease increases the risk of severe COVID-19 and why patients without apparent pre-existing disease develop a severe response requiring admission to intensive care units (ICU). This review will focus on the endocrine mechanisms that control ACE2 and the RAAS system more generally, including the steroid hormones and their receptors that modulate the tissue responsiveness to endocrine actions that may impact SARS-CoV-2 infection and affect the progression of COVID-19 in different patient risk groups. https://joe.bioscientifica.com https://doi.org/10.1530/JOE-20-0260 (c) 2020 Society for Endocrinology Published by Bioscientifica Ltd. Printed in Great Britain 


\section{The RAAS: ACE, ANG II and aldosterone}

Loss of blood volume and poor perfusion of the kidneys is detected by the juxtaglomerular apparatus, which responds by releasing renin. In the circulation, renin cleaves the precursor polypeptide angiotensinogen (produced in the liver) to the decapeptide ANG I (the $\mathrm{N}$-terminal 10 amino acids of angiotensinogen). ACE is expressed predominantly in epithelial cells and performs the next step to remove a dipeptide from the C-terminus to produce the octapeptide ANG II (Coates 2003). ANG II binds to angiotensin receptors type 1 and 2 (AT1R and AT2R, respectively) located in the zona glomerulosa of the adrenal to increase the production of the steroid hormone aldosterone. Aldosterone synthesis and release is also regulated by ACTH and serum potassium levels and together with ANG II, aldosterone serves as a critical physiological regulator of sodium resorption and hence fluid levels via actions at the epithelial MR (Fuller \& Young 2005, Connell et al. 2008).

The first isoform of ACE was identified in the late 1950s as the converting enzyme for ANG I (Bakhle et al. 1969, Ferreira et al. 1970). The ACE gene encodes two isoforms; one is expressed broadly in epithelial cells, capillaries of the lung, kidney and several other tissues, while a truncated germinal form is expressed only in sperm. Point mutations in $A C E$ have been identified that influence tissue ACE levels and impact exercise capacity, underscoring the importance of this rate-limiting step in the systemic and tissue RAAS. ACE is also part of the kinin-kallikrein system (where it is referred to as kinase II) and degrades the vasodilator bradykinin, and other vasoactive peptides. Other roles include its glycosidase activity which releases glycosylphosphatidylinositol (GPI)-anchored proteins from the plasma membrane (Zhao et al. 2015). Of note, ACE and its isozyme ACE2 are the products of distinct genes located on chromosome 17 and the $\mathrm{X}$ chromosome, respectively.

In addition to the systemic RAAS, many tissues express a local 'RAAS' comprising angiotensinogen, the (pro)renin receptor and renin-independent mechanisms of ANG peptide generation from ANG(1-12). Members of the 'depressor' arm of ACE2/ANG(1-7)/MAS receptor (discussed further subsequently) and ANG IV/insulinregulated aminopeptidase pathways (IRAP) have also been identified in a wide range of tissues, including lung, heart and vasculature, CNS, kidney and macrophages among others (Azushima et al. 2020). Although this remains an active area of research, therapeutic regulation of local RAAS components has offered new options for cardiovascular and other diseases (Danser 2003, Pugliese et al. 2020).

\section{ACE2: the 'alternate RAAS'}

ACE2 was first discovered by Acton and colleagues in 2000 by 5'-RACE sequencing of a cDNA library from failing human heart (Donoghue et al. 2000). As an aside, it is intriguing that ACE2 has recently been identified as the most highly upregulated gene in hearts of patients who died with hypertrophic cardiomyopathy (Bos et al. 2020). Although first characterised in heart, kidney and testis - sites where ACE has established functions - multiple and diverse roles for ACE2 have now been described across many tissues, including the lung, gut and inflammatory cells. Its role as the catalytic enzyme that produces ANG(1-7) and ANG(1-9), that in turn activate the MAS receptor, are now the focus of efforts to control cardiovascular disease via novel pharmacological avenues (Povlsen et al. 2020). The MAS receptor, also known as MAS1 oncogene, is a G-protein coupled receptor, which opposes the negative effects of the RAAS when activated by ANG(1-7), that is, inappropriate ANG II, AT1R and MR activation (Povlsen et al. 2020). The blood vessels of human and several other species generate ANG(1-7). The MAS receptor is expressed in both the endothelial and vascular smooth muscle cells (VSMCs) and is thus a target for newer pharmacotherapies (Povlsen et al. 2020). The ACE2/ANG(1-7)/ANG(1-9) pathway is recognised as critical and protective in the pathogenesis of heart failure with reduced or preserved ejection fraction in association with myocardial infarction, hypertension, lung disease and diabetes (Wu et al. 2017).

SARS-CoV and SARS-CoV-2 gain entry to host cells via binding of viral surface spike proteins to the receptorbinding domain of ACE2 (Tai et al. 2020). SARS-CoV-2 differs from SARS-CoV by a number of defined amino acids which increase affinity of the new virus for the ACE2 receptor (Lan et al. 2020). The expression of ACE2 on type 2 pneumocytes provides SARS-CoV-2 with an infection route deep within airways and is likely critical in the development of severe COVID-19. ACE2 is also expressed on macrophages, perivascular pericytes, endothelial cells and cardiomyocytes providing a plausible link between immunity, inflammation, ACE2 and cardiovascular disease and use of the ACE2 cellular internalisation machinery to enter the cell.

The binding of SARS-CoV-2 to ACE2 is primed by protease cleavage of spike proteins. This is catalysed by 
the type II transmembrane serine protease (TMPRSS2). A number of other proteases also perform this step and are co-expressed with ACE2 in some tissues; furin protease TMPRSS, cathepsin $\mathrm{L}$ and human airway trypsin-like protease (HAT) all facilitate viral uptake into host cell endosomes (Hoffmann et al. 2020). However, the role of these proteases in the pathogenicity and high mortality of both SARS-CoV and SARS-CoV-2 remains to be clarified. Once the SARS-CoV-2 bound ACE2 is internalised by the cell, ACE2 is markedly downregulated. This potentially removes the critical protective pathway of the RAAS, allowing unrestrained activity of the tissue renin/ACE/ANG II pathway and promotion of 'macrophage activation syndrome' and the multiorgan hyperinflammatory response (cytokine storm) (Banu et al. 2020). The degree of downregulation of ACE2 is associated with the severity of disease, and thus replacement therapy with recombinant ACE2 has been proposed (Verdecchia et al. 2020). In women, oestrogen (E2) signalling associates with higher levels of ACE2, possibly relevant to the sex difference in the development of severe COVID-19. Enhanced activity of the ACE2 pathway most likely contributes to the reduced incidence of cardiovascular disease in premenopausal women.

\section{Antagonists of the RAAS are key therapies for cardiovascular and renal disease: implications for SARS-CoV-2}

Studies carried out in Wuhan early in the pandemic established cardiovascular disease, and hypertension in particular, as important risk factors for developing severe forms of COVID-19. Obesity and diabetes have now emerged as other prominent risk factors. Many patients with cardiovascular disease and/or hypertension are prescribed ACEi, ARB and MRA therapies to control their blood pressure and to protect the heart and kidneys from adverse remodelling processes. Because these drugs taken alone or in combination can elevate ACE2 expression, concerns were expressed that these important anti-hypertensive drugs could increase susceptibility to viral infection and/or viral load (the number of viral particles) in people taking them. Consistent with this idea, early data from a large UK population study showed a higher incidence of self-reported COVID-19 symptoms in ACEi users. However, there was no increase in COVID-19 symptoms in a subset of patients with confirmed viral infection.
To date, evidence does not support increased susceptibility of hypertensive patients or of patients with heart disease to SARS-CoV-2 infection. However, older patients, and more often males, with these conditions are more likely to develop severe symptoms and die. Very recent reports suggest that those patients who continue taking ACEi/ARB medication have a lower risk of all-cause mortality. As yet, there is no evidence that they alter the severity of COVID-19 disease as noted in the WHO briefing on 7May 2020 (www.who.int/news-room/commentaries/ detail/covid-19-and-the-use-of-angiotensin-convertingenzyme-inhibitors-and-receptor-blockers). However, the increase in ACE2 expression as a result of ACEi or $\mathrm{ARB}$ therapy is likely to be beneficial in countering the SARS-CoV-2-mediated reduction in ACE2 expression, thereby reducing ALI/ARDS. Thus, the potential detrimental consequences of discontinuing RAAS blocking therapies upon pre-existing disease may be substantially greater than any modest effects on susceptibility to infection (Guzik et al. 2020).

Troponin levels are elevated in $>10 \%$ of patients hospitalized for COVID-19, indicating heart failure and myocardial damage; levels are higher in critically ill patients and in those with pre-existing heart disease (Tersalvi et al. 2020). Enhanced myocardial injury may result from the interaction between pathways associated with severe infections and amplified inflammatory response (Tersalvi et al. 2020). SARS-CoV-2 infection downregulates ACE2 in the lung; a similar mechanism in cardiomyocytes may enable the deleterious hyperinflammatory response of COVID-19, leading to cardiomyocyte death (Tersalvi et al. 2020). The role of ACE2 regulation in these disease processes induced by the novel coronavirus is the subject of current investigation.

In summary then, the current consensus is that the presence of hypertension and other cardiovascular diseases do not increase the risk of infection by SARS-CoV-2, but patients with pre-existing heart and vascular disease, including hypertension and diabetes, are at increased risk of a severe course of disease in the event of COVID-19 pneumonia and death (Pranata et al. 2020). It should also be noted that hypotension is a common feature of critical illness and septic shock (Alexandre et al. 2020, Mancia et al. 2020, Reynolds et al. 2020); at any point during infection and subsequent disease course, this hypotension may be exacerbated by antihypertensive medications by virtue of their established mechanisms of action (Park et al. 2020). This may be mediated by a shift in the ACE/ACE2 balance following downregulation of ACE2 tissue activity by COVID-19, resulting in 
unopposed ACE. This, in turn, can induce aldosterone synthesis and subsequently hypokalaemia. MRA, as potassium-sparing diuretics, may have value for correcting this hypokalaemia (Alexandre et al. 2020).

Thromboembolism is emerging as a serious and common complication in critically ill COVID-19 patients. Some reports indicate an incidence of up to $31 \%$ for thrombotic complications in ICU patients with COVID-19 infections (Klok et al. 2020). This may explain the unusual degree of hypoxia observed (Sardu et al. 2020). Indeed, one of the remarkable features of COVID-19 is its association with an unusually low degree of blood oxygenation in the absence of other symptoms (such as problems breathing), associated with high levels of fatigue after exertion. The hyperinflammatory response in critically ill patients promotes platelet activation and stasis and increases susceptibility to thrombotic disease in both the venous and arterial circulations. This may reflect dysfunction of the endothelium (Sardu et al. 2020). Hypertension, a common comorbidity in patients with COVID-19 (as stated previously), is associated with an increased risk of thrombosis - and in particular a 'sepsis-induced coagulopathy' - and may predispose to stroke. Elevation of either serum ANG II or aldosterone is associated with accelerated thrombus formation in microvessels and recruitment of inflammatory cells to the venous system via mechanisms that involve AT2 and AT4 receptors, bradykinin receptor and endothelin receptors suggesting a role for ACE (Senchenkova et al. 2010). SARS-CoV-2 infection is associated with an increased incidence of stroke (Tang et al. 2020) and peripheral ischaemic events. Bowel abnormalities and cholestasis were common findings in patients with COVID-19 and patients who underwent laparotomy frequently had signs of thrombosis of the small vessels (Bhayana et al. 2020). Clinical recommendations for managing all COVID-19 patients admitted to ICU include careful prophylactic management of thrombosis (Hess et al. 2020). Whether endothelial dysfunction underlies this susceptibility to thrombosis in COVID-19 (and any role in this for ACE2) is an important question as it may partially explain the higher risk conferred by conditions typified by endothelial dysfunction, including hypertension and diabetes (Teuwen et al. 2020).

While aldosterone has not been associated with regulation of the catalytic activity of ACE2 and thus ANG(1-7) levels, evidence from mesangial cells suggests that the MRA spironolactone can enhance localisation of AT1 receptors at the cell membrane, limit ANG(1-7) production and increase MAS receptor levels. MR blockade also protects renal podocytes by reducing autophagy via actions on the RAAS (Dong et al. 2019). MRA actions may thus be detrimental or beneficial. Studies by Fukuda et al. (2011) revealed the expression of ACE2 on the brushborder membrane of the proximal convoluted tubules that were substantially reduced by aldosterone infusion via MR regulation of pro-inflammatory NF-kB pathways. The decrease in ACE2 protein was again reversed by administration of spironolactone, indicating that this is an MR-mediated response. Whether ACE2 is similarly regulated by MR/aldosterone in other cells of the kidney awaits further investigation. Recent reports suggest that kidney failure is a potential complication of COVID-19 (plausibly consistent with the rare Kawasaki-like disease in children). However, whether the actions of RAAS inhibitors to prevent proteinuria, and kidney fibrosis and effectively slow the deterioration of renal function in renovascular hypertension or diabetic disease extend to the tissue injury observed in COVID-19 is currently unclear (Guo et al. 2020, Li et al. 2020, Zhang et al. 2020, Zhu et al. 2020).

Human monocytes play a role in the control of the RAAS. They express ACE and ACE2 and a number of other components of the local tissue RAAS (RutkowskaZapala et al. 2015). In monocytes, production of ANG(1-7) was consistent across multiple different cell populations (defined by surface markers) except for nonclassical CD14(+)CD16(++) cells where ANG(1-7) levels were significantly greater than for ANG II. CD14(+) CD16(++) cells have been suggested to have a role in the maintenance of vessel wall homeostasis: generation of ANG II and ANG(1-7) in these cells may contribute to this (Rutkowska-Zapala et al. 2015). Given that CD14(+) CD16(++) cells preferentially associate with the vascular endothelium, and express a vasoprotective phenotype, loss of ACE2 activity in these cells could elicit or promote endothelial cell dysfunction during (or potentially leading to) severe COVID-19. Intriguingly, ACE2 activity is increased in monocyte-derived macrophages from prehypertensive subjects compared with normotensive controls (Keidar et al. 2007); activity that is subsequently lost with progression to hypertension. This raises the possibility of a protective role of ACE2 in the early stage of hypertension that is lost at later stages of disease (Keidar et al. 2005, 2007). Nuclear receptors other than $\mathrm{MR}$, glucocorticoid receptor (GR) and oestrogen receptor (ER) can also regulate ACE2 in these cells, for example, application of a PPAR- $\gamma$ agonist increases ACE2 mRNA in monocyte-derived macrophages from patients with essential hypertension (Li et al. 2012, Patel et al. 2013). 
This accessible cell population may facilitate disease risk stratification by assessing ACE2 levels in patients with hypertension and/or heart disease. MR (as well as the highly related GR; see subsequently) are expressed in monocytes/macrophages and exert potent effects on their differentiation and cellular phenotype, another potential modifier of disease.

\section{Glucocorticoid receptor, corticosteroids and COVID-19}

Given their powerful anti-inflammatory and immunomodulatory effects, corticosteroids are an obvious potential therapy for ALI/ARDS in severe COVID-19. Indeed, based on their potent ability to suppress pro-inflammatory cytokine production (and controversial evidence from clinical trials for ALI/ARDS associated with sepsis or in SARS-infected patients; see subsequently), low-dose dexamethasone, a synthetic glucocorticoid, forms one of the randomisation arms of the large UK-based RECOVERY trial in adults hospitalised for COVID-19 (Lamontagne et al. 2018). At the time of writing, the preliminary findings from the RECOVERY trial comparing dexamethasone $(6 \mathrm{mg} /$ day, once daily for up to 10 days) to usual care showed that dexamethasone reduced the number of deaths in ventilated patients by one-third and in patients receiving oxygen without mechanical ventilation deaths were reduced by one-fifth (Horby et al. 2020). There was no benefit (and the possibility of harm) in patients who did not require oxygen. Recruitment to the dexamethasone arm was closed early due to the clear and dramatic beneficial effect of treatment in severely ill patients.

Glucocorticoids are essential during infection or following trauma. Infection and pro-inflammatory cytokines are powerful activators of the HPA axis (Besedovsky \& del Rey 1996). The consequent increase in circulating glucocorticoid concentrations is critical for survival. Colds, flu and other infections can be rapidly fatal in people with adrenal insufficiency (inadequate corticosteroid production), whether primary (adrenal), or secondary due to insufficient ACTH production in the pituitary. Whether this is also true of infection by SARS-CoV-2 is unknown, but likely; discussed subsequently. In animals, glucocorticoids are essential to survive hypovolemic shock following administration of bacterial lipopolysaccharide (LPS) or pro-inflammatory mediators, such as IL-1 and TNFa (Bertini et al. 1988). Conversely, at the other end of the 'dose range', high levels of glucocorticoids are immunosuppressive and can increase risk of fatal infection, including sepsis. Hitting the optimal level of glucocorticoids at the right time is vital to control infections and restore homeostasis. This is crucial if we are to exploit their essential antiinflammatory properties to treat COVID-19.

Most research on corticosteroid effects on immune function has concerned GR. MR are also expressed in macrophages where they are important mediators of inflammatory macrophage phenotype under certain pathophysiological conditions (Rickard et al. 2009, Usher et al. 2010, Sun et al. 2016). However, given the prevalence of dexamethasone (a largely MR-sparing corticosteroid) in experimental studies and its use in the RECOVERY trial (Lamontagne et al. 2018), here we focus on GR. Nevertheless, the properties and effects of synthetic glucocorticoids such as dexamethasone may be very different from those of cortisol, the physiological ligand they are often equated to, but which binds to both GR and MR. Endogenous glucocorticoid concentrations are also regulated by the $11 \beta$-hydroxysteroid dehydrogenases. The type 2 enzyme (11 $\beta$-HSD2) converts cortisol (and corticosterone) into intrinsically inert cortisone (and 11-dehydrocorticosterone) whereas 11ß-HSD1 catalyses the opposite reaction (Chapman et al. 2013b). Dexamethasone is a poor substrate for $11 \beta$-HSD1. Levels of cortisone/11-dehydrocorticosterone increase following HPA axis activation including after LPS injection (Verma et al. 2018), providing substrate for, and upregulating, $11 \beta$-HSD1 (glucocorticoids as well as pro-inflammatory cytokines increase 11 $\beta$-HSD1 expression in most cells and tissues; (Sai et al. 2008, Morgan et al. 2014)). Whilst $11 \beta$-HSD2 is not normally expressed in immune cells, $11 \beta$-HSD1 is expressed in glucocorticoid targets, such as activated neutrophils or macrophages, where it contributes to intracellular glucocorticoid action, shaping immune responses (Chapman et al. 2013a). Expression in lymphocytes is much lower. In mice, $11 \beta$-HSD1 deficiency increases IL- 6 production by activated macrophages (Gilmour et al. 2006) and increases neutrophil recruitment to sites of inflammation (Coutinho et al. 2016). In a mouse model of experimental malaria, 11ß-HSD1 deficiency increased disease severity and altered parasitaemia, in a parasite strain-dependent manner (Vandermosten et al. 2017), consistent with a contribution by $11 \beta-H S D 1$ to glucocorticoid control of immunity and inflammation.

As well as glucocorticoid concentration, GR density is also important for optimal immune function. Transgenic mice with two extra GR alleles (and increased GR density) show increased resistance to stress and endotoxic shock 
(Reichardt et al. 2000). Conversely, GR haploinsufficient mice show aggravated inflammation in experimental autoimmune encephalomyelitis (a mouse model of multiple sclerosis) and are resistant to disease-suppression by a sub-maximal dose of dexamethasone (Wust et al. 2009). GR down-regulation by dexamethasone may be a mechanism for acquired glucocorticoid resistance following pharmacotherapy. Whether genetic variation in NR3C1 (encoding GR) or HSD11B1 influence susceptibility to infection or severity of disease in COVID-19 will undoubtedly emerge, but genetic variation in NR3C1 associates with high-altitude pulmonary oedema in Han Chinese (Yang et al. 2019) and decline in lung function in cystic fibrosis, with the latter attributed to modulation of inflammatory burden in the lung (Corvol et al. 2007).

An adrenal crisis can present with extreme hypotension and shock, similar to the hyperinflammatory state associated with sepsis or ALI/ARDS (as in severe COVID-19). The requirement for glucocorticoids to survive such a hyperinflammatory state is usually attributed to suppression of pro-inflammatory cytokine and chemokine production (Coutinho \& Chapman 2011), though the role of glucocorticoids in 'homeostatic compensation' in critical illness is likely much more complex than this (Meduri \& Chrousos 2020). In mice, disruption of GR in macrophages increased proinflammatory cytokine levels and mortality in LPSinduced systemic inflammation (Bhattacharyya et al. 2007). This could be rescued by inhibition of p38 MAPK, consistent with pro-inflammatory gene control being vital for GR-mediated immunosuppression and survival. However, it may not be that simple. Mice lacking GR in $\mathrm{T}$ cells are rescued from lethal immune activation by cyclooxygenase- 2 inhibition, but not by neutralisation of cytokines (Brewer et al. 2003). This suggests that cytokine suppression by glucocorticoids in itself is not sufficient to survive an overactive immune response. Survival of endotoxic shock may also require vascular GR. Following LPS injection, mice with endothelial cell disruption of GR showed higher mortality, more haemodynamic instability and higher pro-inflammatory cytokine levels than their controls (Goodwin et al. 2013). Glucocorticoids act on several components of the classical RAS, including increased ATR1 expression on VSMC (Saruta 1996). GR in VSMC contributes to dexamethasone-induced hypertension (Goodwin et al. 2008), though whether GR in VSMC are needed to survive endotoxic shock has not been reported yet. The importance of the endothelial actions of glucocorticoids have also been demonstrated in a mouse model of acute lung injury, in which dexamethasone treatment suppresses endothelial leakage and lung inflammation: simply suppressing proinflammatory cytokine levels was not sufficient to prevent acute lung injury (Vettorazzi et al. 2015). Glucocorticoid enhancement of the barrier function of the lung endothelium was also necessary, to suppress vascular leakage and infiltration of inflammatory cells into the lung. This was dependent on a glucocorticoid-mediated increase in plasma sphingosine 1-phosphate levels. This in turn required intact GR signalling in macrophages to induce SphK1 (encoding sphingosine kinase 1). As is frequently the case with glucocorticoid signalling, context was critical: SphK1 expression was synergistically increased by the combined action of dexamethasone and pro-inflammatory cytokines. Thus, anti-inflammatory effects of glucocorticoids are greatly enhanced in a proinflammatory environment. The timing of this may be critical in vivo. Too rapid or too great a suppression of pro-inflammatory cytokines may result in a less than optimal induction of SphK1 and thus less clinical efficacy of dexamethasone treatment. Contributions of GR in both immune cells and endothelial cells are needed. As well as pro-inflammatory cytokine suppression, glucocorticoids are vital to counter hypotension and hypoglycaemia during shock or infection (B. 2019, Meduri \& Chrousos 2020). Thus, in a mouse model of LPSinduced systemic inflammation coupled with 'ICU' care (mechanical ventilation, crystalloids, norepinephrine), impaired GR function increased mortality, aggravated acute lung injury and increased the level of vasopressor needed to maintain haemodynamic stability (Wepler et al. 2019). In a mouse model of malarial infection, adrenalectomy caused early lethality without affecting parasitemia. This was associated with increased cytokine levels, exhaustion of hepatic glycogen and profound hypoglycaemia that was independent of insulin (Vandermosten et al. 2018). Dexamethasone treatment increased plasma glucose levels and prevented lethality in malaria-infected adrenalectomised mice despite higher levels of parasitemia (Vandermosten et al. 2018). Thus, incompletely understood effects to maintain glycaemia and haemodynamic stability are also critical to the beneficial effects of glucocorticoids during critical illness. However, exogenous glucocorticoid treatment runs the risk of not adequately controlling pathogen replication through immunosuppression and may only go part way to restoring homeostatic compensation in the face of exhaustion of other endocrine and nutritional support (Meduri \& Chrousos 2020). 
Although glucocorticoid pharmacotherapy is normally immunosuppressive, endogenous glucocorticoids are immunomodulatory and shape immune responses, in part by inhibiting the production of pro-inflammatory 'Th1' cytokines, which promote cell-mediated immune responses and are important for killing intracellular parasites including viruses such as SARS-CoV-2 whilst preserving or promoting the production of the 'Th2' cytokines needed for antibody production (Elenkov \& Chrousos 1999). The timing of this switch is crucial. Too late and tissues may be damaged by an over-exuberant Th1 response (e.g. a hyperinflammatory state), too early might allow an infection to persist. Interestingly, the 'Th1'-biased C57Bl/6 strain of mice, which have relatively small adrenal glands, is permissive to infection with the MA15 mouse-adapted strain of SARS-CoV, but resistant to developing clinical disease. On the other hand, BALB/c 'Th2'-biased mice (which have large adrenal glands) are highly susceptible to MA15 infection (Channappanavar \& Perlman 2017). Whilst speculative, this raises the possibility that a Th2 bias and/or higher basal HPA axis activity may increase early viral replication. Macrophages, also an important target of glucocorticoid action, are polarised to a distinct phenotype in vitro, by glucocorticoid exposure (Elenkov, 2004) and differ between C57Bl/6 and $\mathrm{BALB} / \mathrm{c}$ mice. As well as immune cell phenotype, glucocorticoids alter immune cell trafficking. Acutely, they cause lymphopenia and neutrophilia (McEwen et al. 1997). In SARS patients, lymphopenia and neutrophilia were both associated with prevailing serum cortisol levels (Panesar et al. 2004). This raises the possibility that the cortisol response to infection contributes to the alteration in circulating leukocytes. Lymphopenia with neutrophilia also occurs in COVID-19 patients, with the degree of lymphopenia greater in more severe COVID-19. As noted previously the MR also acts in the macrophage to regulate the inflammatory response (Rickard et al. 2009), frequently acting in opposition to GR to facilitate pro-inflammatory and pathophysiological outcomes (Shen et al. 2016). However, any role for MR activation by endogenous cortisol in shaping the response to infection is currently unclear and worthy of investigation (Young 2013). Plausibly, differences in HPA axis activity contribute to the course of disease following SARS-CoV-2 infection. The risk factors for developing severe COVID-19 (older age, cardio-metabolic disease, hypertension) are all associated with dysregulated HPA axis activity. This raises the possibility that dysregulated corticosteroid action contributes to a dysregulated immune response, as implicated in a preclinical model of diabetes with MERS infection (Kulcsar et al. 2019). Whilst highly speculative, this is nevertheless worth exploring.

\section{Corticosteroids in critical illness, sepsis and SARS and lessons for COVID-19}

As mentioned previously, dexamethasone dramatically reduced mortality in critically ill COVID-19 patients requiring respiratory support with the clearest benefit in those treated more than 7 days after treatment onset (Horby et al. 2020). Dexamethasone was without benefit in hospitalised patients not receiving respiratory support, with the results consistent with possible harm in these patients. The authors speculate that the treatment was of most benefit in patients exhibiting inflammatory lung damage. Subsequently, we review the evidence for corticosteroids in inflammatory lung damage, or ALI/ARDS.

ALI/ARDS is associated with septic shock, as well as viral pneumonia following infection with SARS-CoV, SARS-CoV-2 or MERS. Indeed, ALI/ARDS is a frequent complication in critical illness, accounting for $38-50 \%$ of hospital mortality (Tang et al. 2009). Critical illness is often accompanied by hypercortisolemia (Thompson 2003) and has been attributed to stress-induced activation of the HPA axis in an attempt to control the dysregulated immune response. However, it may also involve reduced cortisol clearance (Boonen et al. 2013, Van den Berghe et al. 2013). Prolonged plasma halflife of cortisol may explain low ACTH levels (for the degree of hypercortisolaemia) in critically ill patients. Alternatively, TNF $\alpha$ may inhibit pituitary release of ACTH (Gaillard et al. 1990). However, a substantial proportion of critically ill patients with septic shock have circulating cortisol levels that are inappropriately low for the degree of inflammation. These patients show an attenuated response to exogenous ACTH ('non-responders'), suggesting adrenal resistance to the effects of ACTH and/or relative adrenal insufficiency. Non-responders in septic shock have a poorer prognosis. It has been speculated that adrenal reserve is depleted (adrenal 'exhaustion'), with inability to mount an adequate cortisol response contributing to mortality (Meduri \& Chrousos 2020). The absence of adrenal gland enlargement is predictive of mortality in septic shock (Jung et al. 2011) and adrenal glands of patients who die after long ICU stays are severely depleted of cholesterol esters (Boonen et al. 2014). This relative adrenal insufficiency has prompted trials of corticosteroids in septic shock, with 
the aim of suppressing the hyperinflammatory state and reducing ALI/ARDS. However, whilst it is clear that high dose corticosteroids increase mortality and morbidity, the efficacy of low-dose corticosteroid treatment, usually hydrocortisone or methylprednisolone, in patients with septic shock or with ALI/ARDS due to SARS or MERS infection has been controversial. This partly reflects a lack of standardisation between studies, that is, timing, dose, patient characteristics, with inadequate power in some. Overall, the message is similar for both ALI/ARDS and septic shock: low-dose corticosteroids do appear to reduce morbidity, duration of ICU stay and disease severity scores, particularly in severely ill patients. However, they may also increase the risk of shock reversal at 7 days (Tang et al. 2009, Rochwerg et al. 2018). They also improve oxygenation in ALI/ARDS (Tang et al. 2009). This might be highly relevant to the efficacy of dexamethasone in COVID-19, with its unusually marked hypoxia. BMJ guidelines issued in 2018 make a weak recommendation to administer corticosteroids in all patients with sepsis/ septic shock (Lamontagne et al. 2018). In contrast, early (preventative) treatment with corticosteroids is disadvantageous. In SARS patients, plasma viral load in non-ICU patients was increased by corticosteroids, exacerbating disease (Auyeung et al. 2005), consistent with suppression of a Th1 anti-viral response.

It is possible that critically ill mechanically ventilated patients represent a particular subset of patients with septic shock who may benefit from corticosteroid treatment (Annane et al. 2002). Hydrocortisone+fludrocortisone therapy for 7 days improved outcomes in mechanically ventilated septic shock patients classed as ACTH 'nonresponders' (there was a trend to lower survival in the responders) (Annane et al. 2002). This is reminiscent of the dramatic effect of dexamethasone in COVID-19, where the most dramatic effects were seen in mechanically ventilated patients (Horby et al. 2020). However, caveats apply to the prevalent use of etomidate (an inhibitor of 11beta-hydroxylase and thus adrenal glucocorticoid synthesis), during intubation in mechanically ventilated patients in the septic shock study (Annane et al. 2002). Another study reported that etomidate accounted for the relative adrenal insufficiency in 'non-responder' intubated patients (Malerba et al. 2005). Nevertheless, a Cochrane review of the use of a single induction dose of etomidate for intubation in ICU did not produce strong evidence of an increase in mortality vs other agents (Bruder et al. 2015). Although etomidate is not routinely used in critically ill patients in the UK (for induction during intubation) and is extremely unlikely to account for the dramatic effect of dexamethasone in COVID-19, the acute shortages of drugs used in critical care early in the COVID-19 pandemic may have prompted its use in places. An alternative explanation for poor/non-response to ACTH in severely hypoxic patients is that adrenal sensitivity for ACTH is blunted in hypoxia (Bouissou et al. 1988). Again, this might be especially relevant to COVID-19. Although hypoxia increases adrenal glucocorticoid output (Bloom et al. 1977) across a wide range of arterial $\mathrm{PO}_{2}(17-55 \mathrm{mmHg})$, the normal cortisol increase following exercise is attenuated at high-altitudeinduced hypoxia, though ACTH responds as expected (Bouissou et al. 1988). This raises the possibility that relative adrenal insufficiency may be associated with hypoxemia. Intriguingly, a case has been described where adrenal insufficiency presented with progressive dyspnoea and hypoxaemia due to hypocortisolic myopathy affecting the respiratory muscles. The patient had modest hypercapnia despite severe hypoxia, and thoracic CT showed ground-glass infiltrates (Pirlet et al. 2011).

Reflecting the risk of an Addisonian crisis triggered by SARS-CoV-2 infection, patients with primary and secondary adrenal insufficiency taking glucocorticoid replacement therapy are advised to double the normal corticosteroid replacement dose if they develop a dry cough and fever, in line with 'sick day rules' (Kaiser et al. 2020). Concern also applies to patients prescribed corticosteroids to manage chronic inflammatory conditions. Long-term suppression of the HPA axis due to glucocorticoid pharmacotherapy can lead to adrenal insufficiency in $\sim 50 \%$ of patients. However, there is no evidence as yet to assess whether these patients would benefit from adjustment of their glucocorticoid dose if infected. Once severe disease has developed, corticosteroids are undoubtedly of benefit, based on the evidence for efficacy in the ALI/ARDS associated with COVID-19 in the dexamethasone randomisation arm of the RECOVERY trial. The RECOVERY trial used dexamethasone rather than hydrocortisone to avoid fluid retention, but it is conceivable that an alteration in the balance between GR (activated by dexamethasone and, with lower affinity by hydrocortisone) and MR (activated by hydrocortisone but poorly by dexamethasone) in controlling inflammation may also play a part in the efficacy. The prevalence of relative adrenal insufficiency in COVID-19 is, as yet, unknown. Investigation of HPA axis activity during the course of SARS-CoV-2 infection and illness, particularly in severe illness, would be helpful in directing future therapies for COVID-19 to improve outcomes. 
Endogenous glucocorticoids shape the immune response as it develops (Munck et al. 1984, McEwen et al. 1997, Coutinho \& Chapman 2011) by acting on MR as well as GR. The use of saturating and potent glucocorticoids administered as bolus is by no means equivalent to the ultradian release of endogenous physiological hormones, subject to intracellular metabolism by the immunemodulating $11 \beta$-HSD1. The highly complex and contextdependent effects of glucocorticoids are extremely difficult to mimic in treatment, especially of the complex critically ill patient. The timing of glucocorticoid administration and action need to be exquisitely fine-tuned to capitalise on their life-saving anti-inflammatory effects and avoid detrimental immunosuppression.

\section{Vitamin D: the sunshine hormone}

The term 'vitamin $\mathrm{D}^{\prime}$ refers to a group of compounds, with vitamin $\mathrm{D}_{3}$ being the most important in humans. Like corticosteroids, vitamin D is a sterol molecule. Some vitamin $\mathrm{D}$ is obtained from the diet, but most is produced from 7-dehydrocholesterol (a precursor to cholesterol biosynthesis) by the skin. Vitamin $\mathrm{D}$ is converted to the active hormone, 1,25-dihydroxyvitamin $\mathrm{D}_{3}$ (calcitriol) mainly by the kidney, but in some other cell types as well including pulmonary epithelial cells (Sandhu \& Casale 2010) and immune cells (Baeke et al. 2010). Calcitriol and vitamin D both circulate in the blood. Like GR, the receptor for calcitriol is a member of the nuclear receptor family. Similar to the corticosteroids, vitamin D regulates innate and adaptive immune responses (reviewed, Baeke et al. 2010), non-classical effects that are independent of bone and calcium homeostasis.

The synthesis of vitamin D in skin is dependent upon UV light, specifically UVB light. A number of studies have now linked indicators of sun exposure to incidence of severe COVID-19 (Rhodes et al. 2020). This has led many to suggest that vitamin D - and more specifically, calcitriol - is protective against either infection - given that it is protective against infection with influenza and other respiratory viruses (Martineau et al. 2017) - or COVID-related critical illness (Grant et al. 2020, Ilie et al. 2020). However, a study involving the UK Biobank has shown no association between vitamin $\mathrm{D}$ concentrations and risk of SARS-CoV-2 infection (Hastie et al. 2020). With respect to severe COVID-19, another UK Biobank study (not yet peer-reviewed) has shown that some of the risk factors - older age, obesity, hypertension and being black or ethnic minority at a northern latitude (darker skin), are all associated with lower serum vitamin D levels (Darling et al. 2020). Critical illness is also associated with low serum vitamin $\mathrm{D}$, which often occurs with relative adrenal insufficiency. Chronic critical illness has been suggested to be a state of exhaustion of the capacity to generate important hormones such as corticosteroids and vitamin D (Meduri \& Chrousos 2020). In a recent report, in critically ill COVID-19 patients, low vitamin D status was associated with worse outcome (Alipio et al. 2020). Yet, another (not yet peer-reviewed) study in hospitalised patients across several countries suggests that severe vitamin D deficiency is associated with only a modest increase in risk of severe COVID-19 (17.3\% vs $14.6 \%$ in patients with normal vitamin D levels (Daneshkhah et al. 2020). Thus, causality has not been established and low vitamin D status may be a marker of critical illness rather than a cause. As well as sharing part of its biosynthetic pathway with glucocorticoids, vitamin D also impacts some of the same systems. Like corticosteroids, vitamin D interacts with the RAAS. In mice unable to activate vitamin D (with deletion of 25(OH)D 1alpha-hydroxylase, causing hypertension), calcitriol suppressed renin activity, thereby normalising activity of the classical RAAS and hypertension (Zhou et al. 2008). In a rat model of LPSinduced ALI/ARDS, calcitriol reduced endothelial leakage (Xu et al. 2017). This beneficial effect was attributed to alterations in the balance between the classical RAAS and the ACE2/MAS system: calcitriol inhibited the LPSinduced increase in tissue RAAS in lung (ACE, renin and ANG II) and the LPS-mediated reduction in ACE2 (Xu et al. 2017). However, high calcitriol concentrations were required for the benefit and whether this translates to clinical situations is unclear. Moreover, calcitriol had no effect on the RAAS, including on ACE2 expression in control animals (Xu et al. 2017).

Synergy between vitamin D and glucocorticoid signalling may be relevant to the treatment of steroidresistant asthma - vitamin D improves glucocorticoid sensitivity through modulation of immune tolerance, though exactly how is currently unclear (Pfeffer et al. 2018). There are also some suggestions that vitamin D may protect airways from pathological pollution-induced inflammation (Pfeffer et al. 2018), potentially relevant to the high COVID-19 burden in urban areas and its association with air pollution (Comunian et al. 2020). Based on all of these associations, and others, some have recommended vitamin $\mathrm{D}$ supplementation as a preventative measure against COVID infection and/or severe disease. Although the evidence remains associative, trials have been started for vitamin D treatment in 
high-risk COVID-19 patients (NCT04344041), with results awaited.

\section{The sex steroids, ACE2 and regulation of SARS-CoV-2 mechanisms of disease}

The sex difference in risk of severe COVID-19 noted previously. The proportion of men and women who test positive for SARS-CoV-2 is similar, yet men are $\sim 60 \%$ more likely vs women to become severely ill or die from the complications of COVID-19. Why this occurs is not fully understood but may relate to differences in physiology between men and women (e.g. levels of soluble and membrane ACE2, TMPRS22 or other factors that control ACE2 availability and activity), in behavioural habits or in the rates of co-morbidities. This also reflect well-known sex differences in the immune system including the location of high numbers of genes that reduce or resolve inflammation on the $\mathrm{X}$ chromosomes (Vasanthakumar et al. 2020). However, the sex difference in severe COVID19 risk is different to critically ill patients with sepsis or septic shock, where the mortality is higher in women than in men (Pietropaoli et al. 2010, Sunden-Cullberg et al. 2020) (so presumably independent of sex-dependent corticosteroid differences). It, therefore, raises the possibility of sex differences or sex steroid regulation of ACE/TMPRSS2, other members of RAAS, and potentially target tissues that impact the processing and binding of the viral particle to ACE2 and internalisation of ACE2. Disruption of the ACE2 gene (on the X chromosome) has markedly different effects in males vs females, with the increase in blood pressure in females significantly greater than for males (Shoemaker et al. 2015, 2019), making ACE2 a prime candidate to underlie sex differences in COVID-19. With respect to the circulating RAAS, E2 increases angiotensinogen levels while decreasing renin and angiotensin-converting enzyme (ACE) activity (Pietropaoli et al. 2010). AT1 receptor density and aldosterone production are controlled by $\mathrm{E} 2$ signalling. AT2 receptor density can be increased by E2, as can production of ANG(1-7). While sex-dependent effects of E2 signalling via the oestrogen receptor (ER) have been described for ACE2 expression in a range of tissues, it is currently unknown if this is linked to increased rates of infection and clinical outcomes in women. The incidence of severe of COVID-19 appears to correlate pre-existing cardiovascular disease, hypertension, diabetes, obesity, and so on, which are normally positively modulated by ACE2 expression. Given that females appear relatively 'protected' at every age groups from severe COVID-19, a short-term SARS-CoV-2 mediated loss of ACE2 may impact cardiovascular disease parameters in women. Moreover, loss of ACE2 may suggest an avenue for therapeutic intervention (i.e. ACE2 modulation) that could benefit women in particular, and potentially more so if given earlier in the disease process.

Components of the tissue RAAS and the MR are markedly affected by sex hormones. The cardiac tissue RAAS, aldosterone/MR activation and circulating RAAS all contribute to the onset of diastolic dysfunction, which is more common in older women as a result of hypertension and lower E2 levels after menopause (Zhao et al. 2014). Moreover, diastolic function is inversely correlated to ACE2 activity in females in an E2-dependent manner (da Silva et al. 2017). E2 regulation of ACE2 provides protection against cardiac dysfunction in both females and males by regulating the balance between ACE/ANG II and ACE2/ANG(1-7)/Mas levels (da Silva et al. 2017). Interestingly, mRNA encoding the ER is not altered in many experimental studies of diastolic dysfunction, and instead, E2-dependent downstream effectors (e.g. MAP kinases, ERK1/2) may play a role in the pathology. At physiological levels E2 induces ACE2/Ang1-7 in human umbilical vein endothelial cells (HUVEC) via regulation of ACE1 and ACE2 mRNA expression and activity. This intracellular RAAS, operating independently of the circulating RAAS and in response to E2, could have protective effects upon vascular and endothelial function and heart and kidney disease (Zhao et al. 2014).

Sex differences have also been identified for cardiovascular MR activation. ER modulate MR regulated gene expression in vascular cells, for example intracellular adhesion molecule (ICAM) to affect vessel wall function (Marzolla et al. 2017). The female heart and vasculature are also more susceptible to dysfunction of nitric oxide signalling; in high fat feeding models of diastolic dysfunction the female heart can be protected by MRA or MR deletion in heart or endothelial cells (Jia et al. 2016, 2017, Bienvenu et al. 2017). It is not known if ACE2 or ANG(1-7) play a role in protective mechanisms. Given that MR antagonists also appear to increase ACE2 expression in a range of cell types, there may be an additive effect between ER/MR activation on ACE2 regulation, although this has not been tested.

Similarly, sex differences in the renal tubular RAAS may control the onset of hypertensive renal disease despite robust pressor responses in both sexes. In the Goldblatt model of renovascular hypertension in rats, females show lower blood pressure, lower ACE/ANG II 
but increased levels of ACE2/ANG(1-7)/MAS receptors in the intratubular region; higher ACE2 levels persist with ovariectomy despite elevation of ANG II/AT1R and ACE (Lee et al. 2019). By contrast, males have higher levels of AT1R and a higher AT1R:AT2R ratio vs intact and ovariectomised females (Lee et al. 2019). Higher levels of the ACE2/ANG(1-7)/MAS receptor in hypertensive females compared to hypertensive males will counter the adverse effects of the 'classic' RAAS pathway (Lee et al. 2019). Distinct roles of the cardiovascular regulatory regions of the brain have also been established for blood pressure regulation. Increased central ACE2/ANG(1-7) opposes ACE/ANG II actions by reducing sympathetic output and increasing parasympathetic tone, thereby reducing blood pressure. Females show higher ACE2 activity in the cardiovascular regulatory regions of the brain, that are also driven by actions of E2 (de Morais et al. 2018), potentially also contributing to a protective female phenotype in hypertension.

It now established that $\mathrm{E} 2$ acting via either receptor, ER alpha or beta, modifies aldosterone or MR induced cardiovascular disease pathologies and hypertension (Arias-Loza et al. 2007). As well as regulating ANG II and AT1R expression, E2 may also modify ANG II-mediated aldosterone secretion, adding another layer to sex hormone control of the RAAS (Roesch et al. 2000). Additionally, ACTH release may be regulated by E2, potentially further modifying aldosterone (or glucocorticoid) levels; some studies propose that plasma aldosterone levels are lower in premenopausal women vs men (Miller et al. 1999), and that these differences are absent after menopause (Danser et al. 1998). However, in postmenopausal women, the effect of E2 replacement therapy on plasma aldosterone is not consistent (Seely et al. 1999). Similarly, renin is lower in premenopausal women due to the actions of oestrogen, and this effect is lost after menopause. Thus studies investigating the aldosterone-renin ratio (ARR, the screening tool for suspected primary aldosteronism) in considerably younger (premenopausal) subjects determined that the ARR is significantly higher in 20- to 39 -year-old females vs males, despite lower systolic and diastolic blood pressure (Solanki et al. 2020). Again, this suggests a complex interaction between aldosterone, the MR and sex steroid signalling. Given that progesterone competes with aldosterone for binding to MR, the presence or absence of progestins in hormone replacement therapies may account for some of the variable responses in serum aldosterone levels. Progesterone is well known to be an antagonist of MR (White et al. 2006). Indeed, the MR antagonist spironolactone has been in clinical use for over 60 years and is based on the structure of progesterone. Drospirenone is another synthetic progestin that has retained potent MR antagonist activity. However, it is important to note that while spironolactone is not specific for the MR and can activate the progesterone receptor and antagonise the androgen receptor (AR), its cardioprotective effects are equivalent for both men and women (Pitt et al. 1999).

Evidence supporting a role for androgens in regulation of ACE2 and other components of the cellular machinery required for SARS-CoV-2 infection of cells is more limited than for E2. Genetic and pharmacological studies for RAAS control of cardiovascular and renovascular disease have predominantly been performed in male animals (do Nascimento et al. 2009). Gonadectomy of male rats is linked to worse cardiovascular disease outcomes, and replacement of physiological levels of androgens improves cardiovascular remodelling. In contrast, high levels of exogenous androgens in the form of anabolic steroids drive cardiomyocyte apoptosis, tissue injury, expression of TNF $\alpha$ and activation of cellular RAAS activity (do Nascimento et al. 2009). Whether this is a direct transcriptional response to androgen signalling is not yet known. In studies investigating the effect of flutamide and ovariectomy on blood pressure and renal AT1R mRNA expression in male and female rats, respectively, flutamide had no effect on elevated renal AT1aR mRNA expression (Davis et al. 2019). In contrast, the AR can upregulate TMPRSS2 in prostate cancer cells via direct transactivation that involves chromatin looping with the TMPRSS2 promoter (Chen et al. 2010). These data raise the possibility that androgens may facilitate cell infection by SARS-CoV-2 irrespective of effects on ACE2 levels. Given that spironolactone possesses significant antiandrogenic actions it may be clinically useful for inhibiting the androgen-dependent expression of TMPRSS2 (Liaudet \& Szabo 2020).

At this stage, there are few data suggesting specific sex differences in response to treatment other than survival outcome. The survival advantage in women vs men across all age groups may be in part due to more favourable responses to treatment but implies that continued oestrogen signalling is not the driver of this response, although the greatest difference in survival can be seen in the 50-60-year-old group. Many studies investigating data for sex, age and other variables are hindered by a large heterogeneity in the reporting of patient data in the cohorts tested in some countries. The ZOE blog is a COVID-19 symptom tracker in the UK ZOE (https:// covid.joinzoe.com/post/covid-estrogen-hrt) with nearly 
4 million participants (150,000 respondents). While the data are partly self-reported, they indicate postmenopausal women were not more likely to be hospitalized or need ventilation than those of a similar age who hadn't yet gone through the menopause. Women taking hormone replacement therapy were relatively protected, and those taking the contraceptive pill (with higher levels of estrogen) showed greater protection. The data are likely to be published soon.

There is also conflict in reports as to how ACE2 expression and regulation of RAAS and the peptidases involved in ACE2 shedding, that is, ADAM-17, change with age. For example, Swärd et al. identified an association between soluble (cleaved) ACE2 and COVID-19 risk and propose that soluble ACE2 reveals the overall risk given that ADAM17 cleaves membrane ACE2 and is increased in acute lung injury. Soluble ACE2 is higher in men vs women and higher in adults vs children, consistent with this association (Swärd et al. 2020). While ACE2 expression correlates with susceptibility to SARS-CoV spike protein (SARS-S)-driven entry, Ciaglia et al. indicate that ACE2 levels generally fall in the elderly which leads to increased cardiovascular disease risk but seems counter intuitive to the higher rates of severe disease in these populations (Ciaglia et al. 2020). Whether any of these factors underlie age-dependent outcomes in COVID-19 is the subject of ongoing investigations.

\section{Perspectives, future considerations}

There are many questions arising regarding endocrine impact upon COVID-19. Yet it is also astonishing how much we have already learned. Given the scale of the pandemic and the pace of the associated research, answers to many of the questions identified previously will emerge. If we can harness what we know of the RAAS, both the protective and classical arms, as a modifier of the severity of disease in vulnerable patients, then the burden of this pandemic may be considerably reduced. Numerous studies have sought to develop approaches that predict the response to blockade of the RAAS, enabling a personalized approach to treatment. Blockers of the RAAS are not equal and sex, ethnicity, age, salt intake, baseline renin, ACE or aldosterone - as well as HPA axis activity and genetic variance - remain key variables that impact the individual response to RAAS blockade

\section{Declaration of interest}

The authors declare that there is no conflict of interest that could be perceived as prejudicing the impartiality of this review.

\section{Funding}

M J Y is funded by a Diabetes Australian Diabetes Grant in Aid and the Alice Baker and Eleanor Shaw Gender Equity Fellowship, C D C is funded by NHMRC GNT1127355 and K E C is funded by the MRC (MR/P002811/1, G0800235), the Welcome Trust (212923/Z/18/Z) and a British Heart Foundation Centre of Excellence Award.The authors have no disclosures for work relating to this manuscript.

\section{Acknowledgements}

The authors are grateful to Professors Tim Walsh and Kenneth Baillie for advice on etomidate use in ICU.

\section{References}

Alexandre J, Cracowski JL, Richard V, Bouhanick B \& 'Drugs, COVID-19' working group of the French Society of Pharmacology, Therapeutics 2020 Renin-angiotensin-aldosterone system and COVID-19 infection. Annales d'Endocrinologie 81 63-67. (https://doi.org/10.1016/j. ando.2020.04.005)

Alipio JB, Brockett AT, Fox ME, Tennyson SS, Debettencourt CA, El-Metwally D, Francis NA, Kanold PO, Lobo MK, Roesch MR, et al. 2020 Enduring consequences of perinatal fentanyl exposure in mice. Addiction Biology e12895. (https://doi.org/10.1111/adb.12895)

Annane D, Sebille V, Charpentier C, Bollaert PE, Francois B, Korach JM, Capellier G, Cohen Y, Azoulay E, Troche G, et al. 2002 Effect of treatment with low doses of hydrocortisone and fludrocortisone on mortality in patients with septic shock. JAMA 288 862-871. (https:// doi.org/10.1001/jama.288.7.862)

Arias-Loza PA, Hu K, Dienesch C, Mehlich AM, Konig S, Jazbutyte V, Neyses L, Hegele-Hartung C, Heinrich Fritzemeier K \& Pelzer T 2007 Both estrogen receptor subtypes, alpha and beta, attenuate cardiovascular remodeling in aldosterone salt-treated rats. Hypertension 50 432-438. (https://doi.org/10.1161/HYPERTENSIONAHA.106.084798)

Auyeung TW, Lee JS, Lai WK, Choi CH, Lee HK, Lee JS, Li PC, Lok KH, Ng YY, Wong WM, et al. 2005 The use of corticosteroid as treatment in SARS was associated with adverse outcomes: a retrospective cohort study. Journal of Infection 51 98-102. (https://doi.org/10.1016/j. jinf.2004.09.008)

Azushima K, Morisawa N, Tamura K \& Nishiyama A 2020 Recent research advances in renin-angiotensin-aldosterone system receptors. Current Hypertension Reports 22 22. (https://doi.org/10.1007/s11906020-1028-6)

Baeke F, Takiishi T, Korf H, Gysemans C \& Mathieu C 2010 Vitamin D: modulator of the immune system. Current Opinion in Pharmacology 10 482-496. (https://doi.org/10.1016/j.coph.2010.04.001)

Bakhle YS, Reynard AM \& Vane JR 1969 Metabolism of the angiotensins in isolated perfused tissues. Nature 222 956-959. (https://doi. org/10.1038/222956a0)

Banu N, Panikar SS, Leal LR \& Leal AR 2020 Protective role of ACE2 and its downregulation in SARS-CoV-2 infection leading to macrophage activation syndrome: therapeutic implications. Life Sciences $\mathbf{2 5 6}$ 117905. (https://doi.org/10.1016/j.lfs.2020.117905)

Bertini R, Bianchi M \& Ghezzi P 1988 Adrenalectomy sensitizes mice to the lethal effects of interleukin-1 and tumor necrosis factor. Journal of Experimental Medicine 167 1708-1712. (https://doi.org/10.1084/ jem.167.5.1708)

Besedovsky HO \& Del Rey A 1996 Immune-neuro-endocrine interactions: facts and hypotheses. Endocrine Reviews 17 64-102. (https://doi. org/10.1210/edrv-17-1-64)

Bhattacharyya S, Brown DE, Brewer JA, Vogt SK \& Muglia LJ 2007 Macrophage glucocorticoid receptors regulate Toll-like receptor-4- 
mediated inflammatory responses by selective inhibition of p38 MAP kinase. Blood 109 4313-4319. (https://doi.org/10.1182/blood-200610-048215)

Bhayana R, Som A, Li MD, Carey DE, Anderson MA, Blake MA, Catalano O, Gee MS, Hahn PF, Harisinghani M, et al. 2020 Abdominal imaging findings in COVID-19: preliminary observations. Radiology 201908. (https://doi.org/10.1148/radiol.2020201908)

Bienvenu LA, Morgan J, Reichelt ME, Delbridge LMD \& Young MJ 2017 Chronic in vivo nitric oxide deficiency impairs cardiac functional recovery after ischemia in female (but not male) mice. Journal of Molecular and Cellular Cardiology 112 8-15. (https://doi.org/10.1016/j. yjmcc.2017.08.012)

Bloom SR, Edwards AV \& Hardy RN 1977 Adrenal and pancreatic endocrine responses to hypoxia and hypercapnia in the calf. Journal of Physiology 269 131-154. (https://doi.org/10.1113/jphysiol.1977. sp011896)

Boonen E, Vervenne H, Meersseman P, Andrew R, Mortier L, Declercq PE, Vanwijngaerden YM, Spriet I, Wouters PJ, Vander Perre S, et al. 2013 Reduced cortisol metabolism during critical illness. New England Journal of Medicine 368 1477-1488. (https://doi.org/10.1056/ NEJMoa1214969)

Boonen E, Langouche L, Janssens T, Meersseman P, Vervenne H, De Samblanx E, Pironet Z, Van Dijck L, Vander Perre S, Derese I, et al. 2014 Impact of duration of critical illness on the adrenal glands of human intensive care patients. Journal of Clinical Endocrinology and Metabolism 99 4214-4222. (https://doi.org/10.1210/jc.2014-2429)

Bos JM, Hebl VB, Oberg AL, Sun Z, Herman DS, Teekakirikul P, Seidman JG, Seidman CE, Dos Remedios CG, Maleszewski JJ, et al. 2020 Marked up-regulation of ACE2 in hearts of patients with obstructive hypertrophic cardiomyopathy: implications for SARSCoV-2-mediated COVID-19. Mayo Clinic Proceedings 95 1354-1368. (https://doi.org/10.1016/j.mayocp.2020.04.028)

Bouissou P, Fiet J, Guezennec CY \& Pesquies PC 1988 Plasma adrenocorticotrophin and cortisol responses to acute hypoxia at rest and during exercise. European Journal of Applied Physiology and Occupational Physiology 57 110-113. (https://doi.org/10.1007/ BF00691248)

Brewer JA, Khor B, Vogt SK, Muglia LM, Fujiwara H, Haegele KE, Sleckman BP \& Muglia LJ 2003 T-cell glucocorticoid receptor is required to suppress COX-2-mediated lethal immune activation. Nature Medicine 9 1318-1322. (https://doi.org/10.1038/nm895)

Bruder EA, Ball IM, Ridi S, Pickett W \& Hohl C 2015 Single induction dose of etomidate versus other induction agents for endotracheal intubation in critically ill patients. Cochrane Database of Systematic Reviews 1 CD010225. (https://doi.org/10.1002/14651858.CD010225. pub2)

Channappanavar R \& Perlman S 2017 Pathogenic human coronavirus infections: causes and consequences of cytokine storm and immunopathology. Seminars in Immunopathology 39 529-539. (https:// doi.org/10.1007/s00281-017-0629-x)

Chapman KE, Coutinho AE, Zhang Z, Kipari T, Savill JS \& Seckl JR $2013 a$ Changing glucocorticoid action: $11 \beta$-hydroxysteroid dehydrogenase type 1 in acute and chronic inflammation. Journal of Steroid Biochemistry and Molecular Biology 137 82-92. (https://doi. org/10.1016/j.jsbmb.2013.02.002)

Chapman KE, Holmes MC \& Seckl JR 2013b 11ß-Hydroxysteroid dehydrogenases: intracellular gate-keepers of tissue glucocorticoid action. Physiological Reviews 93 1139-1206. (https://doi.org/10.1152/ physrev.00020.2012)

Chen YW, Lee MS, Lucht A, Chou FP, Huang W, Havighurst TC, Kim K, Wang JK, Antalis TM, Johnson MD, et al. 2010 TMPRSS2, a serine protease expressed in the prostate on the apical surface of luminal epithelial cells and released into semen in prostasomes, is misregulated in prostate cancer cells. American Journal of Pathology 176 2986-2996. (https://doi.org/10.2353/ajpath.2010.090665)
Ciaglia E, Vecchione C \& Puca AA 2020 COVID-19 infection and circulating ACE2 levels: protective role in women and children. Frontiers in Pediatrics 8 206. (https://doi.org/10.3389/fped.2020.00206)

Coates D 2003 The angiotensin converting enzyme (ACE). International Journal of Biochemistry and Cell Biology 35 769-773. (https://doi. org/10.1016/s1357-2725(02)00309-6)

Comunian S, Dongo D, Milani C \& Palestini P 2020 Air pollution and Covid-19: the role of particulate matter in the spread and increase of Covid-19's morbidity and mortality. International Journal of Environmental Research and Public Health 17 4487. (https://doi. org/10.3390/ijerph17124487)

Connell JM, Mackenzie SM, Freel EM, Fraser R \& Davies E 2008 A lifetime of aldosterone excess: long-term consequences of altered regulation of aldosterone production for cardiovascular function. Endocrine Reviews 29 133-154. (https://doi.org/10.1210/er.2007-0030)

Corvol H, Nathan N, Charlier C, Chadelat K, Le Rouzic P, Tabary O, Fauroux B, Henrion-Caude A, Feingold J, Boelle PY, et al. 2007 Glucocorticoid receptor gene polymorphisms associated with progression of lung disease in young patients with cystic fibrosis. Respiratory Research 8 88. (https://doi.org/10.1186/1465-9921-8-88)

Coutinho AE \& Chapman KE 2011 The anti-inflammatory and immunosuppressive effects of glucocorticoids, recent developments and mechanistic insights. Molecular and Cellular Endocrinology 335 2-13. (https://doi.org/10.1016/j.mce.2010.04.005)

Coutinho AE, Kipari TM, Zhang Z, Esteves CL, Lucas CD, Gilmour JS, Webster SP, Walker BR, Hughes J, Savill JS, et al. 2016 11Betahydroxysteroid dehydrogenase type 1 is expressed in neutrophils and restrains an inflammatory response in male mice. Endocrinology 157 2928-2936. (https://doi.org/10.1210/en.2016-1118)

Da Silva JS, Gabriel-Costa D, Wang H, Ahmad S, Sun X, Varagic J, Sudo RT, Ferrario CM, Dell Italia LJ, Sudo GZ, et al. 2017 Blunting of cardioprotective actions of estrogen in female rodent heart linked to altered expression of cardiac tissue chymase and ACE2. Journal of the Renin-Angiotensin-Aldosterone System 181470320317722270 . (https:// doi.org/10.1177/1470320317722270)

Daneshkhah A, Agrawal V, Eshein A, Subramanian H, Roy HK \& Backman V 2020 The possible role of vitamin D in suppressing cytokine storm and associated mortality in COVID-19 patients. mediRxiv. (https://doi.org/10.1101/2020.04.08.20058578)

Danser AH 1996 Local renin-angiotensin systems. Molecular and Cellular Biochemistry 157 211-216. (https://doi.org/10.1007/BF00227900)

Danser AH 2003 Local renin-angiotensin systems: the unanswered questions. International Journal of Biochemistry and Cell Biology 35 759-768. (https://doi.org/10.1016/s1357-2725(02)00178-4)

Danser AH, Derkx FH, Schalekamp MA, Hense HW, Riegger GA \& Schunkert H 1998 Determinants of interindividual variation of renin and prorenin concentrations: evidence for a sexual dimorphism of (pro)renin levels in humans. Journal of Hypertension 16 853-862. (https://doi.org/10.1097/00004872-199816060-00017)

Darling AL, Ahmadi KR, Ward KA, Harvey NC, Couto Alves A, DunnWaters DK, Lanham-New SA, Cooper C \& Blackbourn DJ 2020 Vitamin D status, body mass index, ethnicity and COVID-19: initial analysis of the first-reported UK Biobank COVID-19 positive cases (n 580) compared with negative controls (n 723). medRxiv. (https://doi. org/10.1101/2020.04.29.20084277)

Davis GK, Intapad S, Newsome AD, Coats LE, Bamrick DR, Ojeda NB \& Alexander BT 2019 Androgen receptor blockade differentially regulates blood pressure in growth-restricted versus ovarian deficient rats. Hypertension 74 975-982. (https://doi.org/10.1161/ HYPERTENSIONAHA.119.13257)

De Morais SDB, Shanks J \& Zucker IH 2018 Integrative physiological aspects of brain RAS in hypertension. Current Hypertension Reports 20 10. (https://doi.org/10.1007/s11906-018-0810-1)

Do Nascimento GR, Barros YV, Wells AK \& Khalil RA 2009 Research into specific modulators of vascular sex hormone receptors https://joe.bioscientifica.com https://doi.org/10.1530/JOE-20-0260 (c) 2020 Society for Endocrinology Published by Bioscientifica Ltd. Printed in Great Britain 
in the management of postmenopausal cardiovascular disease. Current Hypertension Reviews 5 283-306. (https://doi. org/10.2174/157340209789587717)

Dong D, Fan TT, Ji YS, Yu JY, Wu S \& Zhang L 2019 Spironolactone alleviates diabetic nephropathy through promoting autophagy in podocytes. International Urology and Nephrology 51 755-764. (https:// doi.org/10.1007/s11255-019-02074-9)

Donoghue M, Hsieh F, Baronas E, Godbout K, Gosselin M, Stagliano N, Donovan M, Woolf B, Robison K, Jeyaseelan R, et al. 2000 A novel angiotensin-converting enzyme-related carboxypeptidase (ACE2) converts angiotensin I to angiotensin 1-9. Circulation Research 87 E1-E9. (https://doi.org/10.1161/01.res.87.5.e1)

Elenkov IJ 2004 Glucocorticoids and the Th1/Th2 balance. Annals of the New York Academy of Sciences 1024 138-146. (https://doi.org/10.1196/ annals.1321.010)

Elenkov IJ \& Chrousos GP 1999 Stress hormones, Th1/Th2 patterns, Pro/ anti-inflammatory cytokines and susceptibility to disease. Trends in Endocrinology and Metabolism 10 359-368. (https://doi.org/10.1016/ s1043-2760(99)00188-5)

Ferreira SH, Bartelt DC \& Greene LJ 1970 Isolation of bradykininpotentiating peptides from Bothrops jararaca venom. Biochemistry 9 2583-2593. (https://doi.org/10.1021/bi00815a005)

Fukuda S, Horimai C, Harada K, Wakamatsu T, Fukasawa H, Muto S, Itai A \& Hayashi M 2011 Aldosterone-induced kidney injury is mediated by NFkappaB activation. Clinical and Experimental Nephrology 15 41-49. (https://doi.org/10.1007/s10157-010-0373-1)

Fuller PJ \& Young MJ 2005 Mechanisms of mineralocorticoid action. Hypertension 46 1227-1235. (https://doi.org/10.1161/01. HYP.0000193502.77417.17)

Funder JW, Pearce PT, Smith R \& Campbell J 1989 Vascular type I aldosterone binding sites are physiological mineralocorticoid receptors. Endocrinology 125 2224-2226. (https://doi.org/10.1210/ endo-125-4-2224)

Gaillard RC, Turnill D, Sappino P \& Muller AF 1990 Tumor necrosis factor alpha inhibits the hormonal response of the pituitary gland to hypothalamic releasing factors. Endocrinology 127 101-106. (https:// doi.org/10.1210/endo-127-1-101)

Gilmour JS, Coutinho AE, Cailhier JF, Man TY, Clay M, Thomas G, Harris HJ, Mullins JJ, Seckl JR, Savill JS, et al. 2006 Local amplification of glucocorticoids by $11 \beta$-hydroxysteroid dehydrogenase type 1 promotes macrophage phagocytosis of apoptotic leukocytes. Journal of Immunology 176 7605-7611. (https://doi.org/10.4049/ jimmunol.176.12.7605)

Goldblatt H, Lynch J, Hanzal RF \& Summerville WW 1934 Studies on experimental hypertension: I. The production of persistent elevation of systolic blood pressure by means of renal ischemia. Journal of Experimental Medicine 59 347-379. (https://doi.org/10.1084/ jem.59.3.347)

Goodwin JE, Zhang J \& Geller DS 2008 A critical role for vascular smooth muscle in acute glucocorticoid-induced hypertension. Journal of the American Society of Nephrology 19 1291-1299. (https://doi. org/10.1681/ASN.2007080911)

Goodwin JE, Feng Y, Velazquez H \& Sessa WC 2013 Endothelial glucocorticoid receptor is required for protection against sepsis. PNAS 110 306-311. (https://doi.org/10.1073/pnas.1210200110)

Grant WB, Lahore H, Mcdonnell SL, Baggerly CA, French CB, Aliano JL \& Bhattoa HP 2020 Evidence that vitamin D supplementation could reduce risk of influenza and COVID-19 infections and deaths. Nutrients 12 988. (https://doi.org/10.3390/nu12040988)

Gross F \& Lichtlen P 1958 Increased pressor activity of renin, hypertensive peptides and adrenergic agents after nephrectomy and cortexon and table salt overdosage in the rat. Naunyn-Schmiedebergs Archiv fur Experimentelle Pathologie und Pharmakologie 233 323-337.

Grossman AB 2019 Addison disease - hormonal and metabolic disorders. MSD Manuals. Kenilworth, NJ, USA: Merck Sharp \& Dohme Corp. (available at: https://www.msdmanuals.com/professional/endocrineand-metabolic-disorders/adrenal-disorders/addison-disease)

Guo W, Li M, Dong Y, Zhou H, Zhang Z, Tian C, Qin R, Wang H, Shen Y, Du K, et al. 2020 Diabetes is a risk factor for the progression and prognosis of COVID-19. Diabetes/Metabolism Research and Reviews e3319. (https://doi.org/10.1002/dmrr.3319)

Guzik TJ, Mohiddin SA, Dimarco A, Patel V, Savvatis K, Marelli-Berg FM, Madhur MS, Tomaszewski M, Maffia P, D'acquisto F, et al. 2020 COVID-19 and the cardiovascular system: implications for risk assessment, diagnosis, and treatment options. Cardiovascular Research 116 1666-1687. (https://doi.org/10.1093/cvr/cvaa106)

Hastie CE, Mackay DF, Ho F, Celis-Morales CA, Katikireddi SV, Niedzwiedz CL, Jani BD, Welsh P, Mair FS, Gray SR, et al. 2020 Vitamin D concentrations and COVID-19 infection in UK Biobank. Diabetology and Metabolic Syndrome 14 561-565. (https://doi. org/10.1016/j.dsx.2020.04.050)

Hess DC, Eldahshan W \& Rutkowski E 2020 COVID-19-related stroke. Translational Stroke Research 11 322-325. (https://doi.org/10.1007/ s12975-020-00818-9)

Hoffmann M, Kleine-Weber H, Schroeder S, Kruger N, Herrler T, Erichsen S, Schiergens TS, Herrler G, Wu NH, Nitsche A, et al. 2020 SARS-CoV-2 cell entry depends on ACE2 and TMPRSS2 and is blocked by a clinically proven protease inhibitor. Cell 181 271.e8-280.e8. (https://doi.org/10.1016/j.cell.2020.02.052)

Horby P, Lim WS, Emberson J, Mafham M, Bell J, Linsell L, Staplin N, Brightling C, Ustianowski A, Elmahi E, et al. 2020 Effect of dexamethasone in hospitalized patients with COVID-19 - preliminary report. medRxiv. (https://doi.org/10.1101/2020.06.22.20137273)

Ilie PC, Stefanescu S \& Smith L 2020 The role of vitamin D in the prevention of coronavirus disease 2019 infection and mortality. Aging Clinical and Experimental Research 32 1195-1198. (https://doi. org/10.1007/s40520-020-01570-8)

Jia G, Habibi J, Aroor AR, Martinez-Lemus LA, Demarco VG, RamirezPerez FI, Sun Z, Hayden MR, Meininger GA, Mueller KB, et al. 2016 Endothelial mineralocorticoid receptor mediates diet-induced aortic stiffness in females. Circulation Research 118 935-943. (https://doi. org/10.1161/CIRCRESAHA.115.308269)

Jia G, Jia Y \& Sowers JR 2017 Role of mineralocorticoid receptor activation in cardiac diastolic dysfunction. Biochimica et Biophysica Acta: Molecular Basis of Disease 1863 2012-2018. (https://doi. org/10.1016/j.bbadis.2016.10.025)

Jung B, Nougaret S, Chanques G, Mercier G, Cisse M, Aufort S, Gallix B, Annane D \& Jaber S 2011 The absence of adrenal gland enlargement during septic shock predicts mortality: a computed tomography study of 239 patients. Anesthesiology 115 334-343. (https://doi.org/10.1097/ ALN.0b013e318225cfd7)

Kaiser UB, Mirmira RG \& Stewart PM 2020 Our response to COVID-19 as endocrinologists and diabetologists. Journal of Clinical Endocrinology and Metabolism 105 1299-1301. (https://doi.org/10.1210/clinem/ dgaa148)

Keidar S, Gamliel-Lazarovich A, Kaplan M, Pavlotzky E, Hamoud S, Hayek T, Karry R \& Abassi Z 2005 Mineralocorticoid receptor blocker increases angiotensin-converting enzyme 2 activity in congestive heart failure patients. Circulation Research 97 946-953. (https://doi. org/10.1161/01.RES.0000187500.24964.7A)

Keidar S, Strizevsky A, Raz A \& Gamliel-Lazarovich A 2007 ACE2 activity is increased in monocyte-derived macrophages from prehypertensive subjects. Nephrology, Dialysis, Transplantation 22 597-601. (https://doi. org/10.1093/ndt/gfl632)

Klok FA, Kruip MJHA, Van Der Meer NJM, Arbous MS, Gommers D, Kant KM, Kaptein FHJ, Van Paassen J, Stals MAM, Huisman MV, et al. 2020 Confirmation of the high cumulative incidence of thrombotic complications in critically ill ICU patients with COVID-19: an updated analysis. Thrombosis Research 191 148-150. (https://doi. org/10.1016/j.thromres.2020.04.041) https://joe.bioscientifica.com

https://doi.org/10.1530/JOE-20-0260
(C) 2020 Society for Endocrinology Published by Bioscientifica Ltd. Printed in Great Britain 
Kulcsar KA, Coleman CM, Beck SE \& Frieman MB 2019 Comorbid diabetes results in immune dysregulation and enhanced disease severity following MERS-CoV infection. JCI Insight 4 e131774. (https://doi.org/10.1172/jci.insight.131774)

Lamontagne F, Rochwerg B, Lytvyn L, Guyatt GH, Moller MH, Annane D, Kho ME, Adhikari NKJ, Machado F, Vandvik PO, et al. 2018 Corticosteroid therapy for sepsis: a clinical practice guideline. BMJ 362 k3284. (https://doi.org/10.1136/bmj.k3284)

Lan J, Ge J, Yu J, Shan S, Zhou H, Fan S, Zhang Q, Shi X, Wang Q Zhang L, et al. 2020 Structure of the SARS-CoV-2 spike receptorbinding domain bound to the ACE2 receptor. Nature $581215-220$. (https://doi.org/10.1038/s41586-020-2180-5)

Lee SH, Lee YH, Jung SW, Kim DJ, Park SH, Song SJ, Jeong KH, Moon JY, Ihm CG, Lee TW, et al. 2019 Sex-related differences in the intratubular renin-angiotensin system in two-kidney, one-clip hypertensive rats. American Journal of Physiology: Renal Physiology 317 F670-F682. (https://doi.org/10.1152/ajprenal.00451.2018)

Leung PS 2004 The peptide hormone angiotensin II: its new functions in tissues and organs. Current Protein and Peptide Science 5 267-273. (https://doi.org/10.2174/1389203043379693)

Li YQ, Wang SJ, Wang CX, Gao DF, Ding KN \& Niu XL 2012 Effect of peroxisome proliferator activated receptor gamma agonist on angiotensin converting enzyme 2 mRNA expression in monocytederived macrophages of essential hypertensive patients. Zhongguo Yi Xие Ke Xие Yuan Xuе Bao 34 379-383. (https://doi.org/10.3881/j. issn.1000-503X.2012.04.013)

Li J, Wang X, Chen J, Zuo X, Zhang H \& Deng A 2020 COVID-19 infection may cause ketosis and ketoacidosis. Diabetes, Obesity and Metabolism [epub]. (https://doi.org/10.1111/dom.14057)

Liaudet L \& Szabo C 2020 Blocking mineralocorticoid receptor with spironolactone may have a wide range of therapeutic actions in severe COVID-19 disease. Critical Care 24 318. (https://doi.org/10.1186/ s13054-020-03055-6)

Malerba G, Romano-Girard F, Cravoisy A, Dousset B, Nace L, Levy B \& Bollaert PE 2005 Risk factors of relative adrenocortical deficiency in intensive care patients needing mechanical ventilation. Intensive Care Medicine 31 388-392. (https://doi.org/10.1007/s00134-004-2550-8)

Mancia G, Rea F, Ludergnani M, Apolone G \& Corrao G 2020 Reninangiotensin-aldosterone system blockers and the risk of Covid19. New England Journal of Medicine 382 2431-2440. (https://doi. org/10.1056/NEJMoa2006923)

Martineau AR, Jolliffe DA, Hooper RL, Greenberg L, Aloia JF, Bergman P, Dubnov-Raz G, Esposito S, Ganmaa D, Ginde AA, et al. 2017 Vitamin D supplementation to prevent acute respiratory tract infections: systematic review and meta-analysis of individual participant data. BMJ 356 i6583. (https://doi.org/10.1136/bmj.i6583)

Marzolla V, Armani A, Mammi C, Moss ME, Pagliarini V, Pontecorvo L, Antelmi A, Fabbri A, Rosano G, Jaffe IZ, et al. 2017 Essential role of ICAM-1 in aldosterone-induced atherosclerosis. International Journal of Cardiology 232 233-242. (https://doi.org/10.1016/j. ijcard.2017.01.013)

Mcewen BS, Biron CA, Brunson KW, Bulloch K, Chambers WH, Dhabhar FS, Goldfarb RH, Kitson RP, Miller AH, Spencer RL, et al. 1997 The role of adrenocorticoids as modulators of immune function in health and disease: neural, endocrine and immune interactions. Brain Research: Brain Research Reviews 23 79-133. (https://doi. org/10.1016/s0165-0173(96)00012-4)

Meduri GU \& Chrousos GP 2020 General adaptation in critical illness: glucocorticoid receptor-alpha master regulator of homeostatic corrections. Frontiers in Endocrinology 11 161. (https://doi. org/10.3389/fendo.2020.00161)

Miller JA, Anacta LA \& Cattran DC 1999 Impact of gender on the renal response to angiotensin II. Kidney International 55 278-285. (https:// doi.org/10.1046/j.1523-1755.1999.00260.x)

Morgan SA, Mccabe EL, Gathercole LL, Hassan-Smith ZK, Larner DP, Bujalska IJ, Stewart PM, Tomlinson JW \& Lavery GG 2014 11beta-
HSD1 is the major regulator of the tissue-specific effects of circulating glucocorticoid excess. PNAS 111 E2482-E2491. (https://doi. org/10.1073/pnas.1323681111)

Munck A, Guyre PM \& Holbrook NJ 1984 Physiological functions of glucocorticoids in stress and their relationship to pharmacological actions. Endocrine Reviews 5 25-44.

Panesar NS, Lam CW, Chan MH, Wong CK \& Sung JJ 2004 Lymphopenia and neutrophilia in SARS are related to the prevailing serum cortisol. European Journal of Clinical Investigation 34 382-384. (https://doi. org/10.1111/j.1365-2362.2004.01347.x)

Park S, Lee HY, Cho EJ, Sung KC, Kim J, Kim DH, Ihm SH, Kim KI, Sohn IS, Chung WJ, et al. 2020 Is the use of RAS inhibitors safe in the current era of COVID-19 pandemic? Clinical Hypertension 2611. (https://doi.org/10.1186/s40885-020-00144-0)

Patel SK, Velkoska E \& Burrell LM 2013 Emerging markers in cardiovascular disease: where does angiotensin-converting enzyme 2 fit in? Clinical and Experimental Pharmacology and Physiology 40 551-559. (https://doi.org/10.1111/1440-1681.12069)

Pearce P \& Funder JW 1987 High affinity aldosterone binding sites (type I receptors) in rat heart. Clinical and Experimental Pharmacology and Physiology 14 859-866. (https://doi.org/10.1111/j.1440-1681.1987. tb02422.x)

Pfeffer PE, Lu H, Mann EH, Chen YH, Ho TR, Cousins DJ, Corrigan C, Kelly FJ, Mudway IS \& Hawrylowicz CM 2018 Effects of vitamin D on inflammatory and oxidative stress responses of human bronchial epithelial cells exposed to particulate matter. PLOS ONE 13 e0200040. (https://doi.org/10.1371/journal.pone.0200040)

Phillips MI \& Schmidt-Ott KM 1999 The discovery of renin 100 years ago. News in Physiological Sciences 14 271-274. (https://doi.org/10.1152/ physiologyonline.1999.14.6.271)

Pietropaoli AP, Glance LG, Oakes D \& Fisher SG 2010 Gender differences in mortality in patients with severe sepsis or septic shock. Gender Medicine 7 422-437. (https://doi.org/10.1016/j.genm.2010.09.005)

Pirlet C, Beck E, Scheen AJ, Duysinx B \& Corhay J-L 2011 Hypocortisolism induces chronic respiratory failure. Respiratory Medicine CME 4 107-108. (https://doi.org/10.1016/j. rmedc.2011.01.006)

Pitt B, Zannad F, Remme WJ, Cody R, Castaigne A, Perez A, Palensky J \& Wittes J 1999 The effect of spironolactone on morbidity and mortality in patients with severe heart failure. Randomized Aldactone Evaluation Study Investigators. New England Journal of Medicine 341 709-717. (https://doi.org/10.1056/NEJM199909023411001)

Povlsen AL, Grimm D, Wehland M, Infanger M \& Kruger M 2020 The vasoactive Mas receptor in essential hypertension. Journal of Clinical Medicine 9. (https://doi.org/10.3390/jcm9010267)

Pranata R, Huang I, Lim MA, Wahjoepramono EJ \& July J 2020 Impact of cerebrovascular and cardiovascular diseases on mortality and severity of COVID-19 - systematic review, meta-analysis, and meta-regression. Journal of Stroke and Cerebrovascular Diseases 29 104949. (https://doi. org/10.1016/j.jstrokecerebrovasdis.2020.104949)

Pugliese NR, Masi S \& Taddei S 2020 The renin-angiotensin-aldosterone system: a crossroad from arterial hypertension to heart failure. Heart Failure Reviews 25 31-42. (https://doi.org/10.1007/s10741-01909855-5)

Reichardt HM, Umland T, Bauer A, Kretz O \& Schütz G 2000 Mice with an increased glucocorticoid receptor gene dosage show enhanced resistance to stress and endotoxic shock. Molecular and Cellular Biology 20 9009-9017. (https://doi.org/10.1128/mcb.20.23.90099017.2000)

Reynolds HR, Adhikari S, Pulgarin C, Troxel AB, Iturrate E, Johnson SB, Hausvater A, Newman JD, Berger JS, Bangalore S, et al. 2020 Reninangiotensin-aldosterone system inhibitors and risk of Covid-19. New England Journal of Medicine 382 2441-2448. (https://doi.org/10.1056/ NEJMoa2008975

Rhodes JM, Subramanian S, Laird E \& Kenny RA 2020. Editorial: low population mortality from COVID-19 in countries south of latitude https://joe.bioscientifica.com

https://doi.org/10.1530/JOE-20-0260 (c) 2020 Society for Endocrinology Published by Bioscientifica Ltd. Printed in Great Britain 
35 degrees North supports vitamin D as a factor determining severity. Alimentary Pharmacology and Therapeutics 51 1434-1437.

Rickard AJ, Morgan J, Tesch G, Funder JW, Fuller PJ \& Young MJ 2009 Deletion of mineralocorticoid receptors from macrophages protects against deoxycorticosterone/salt-induced cardiac fibrosis and increased blood pressure. Hypertension 54 537-543. (https://doi org/10.1161/HYPERTENSIONAHA.109.131110)

Rochwerg B, Oczkowski SJ, Siemieniuk RAC, Agoritsas T, Belley-Cote E, D'aragon F, Duan E, English S, Gossack-Keenan K, Alghuroba M, et al. 2018 Corticosteroids in sepsis: an updated systematic review and meta-analysis. Critical Care Medicine 46 1411-1420. (https://doi. org/10.1097/CCM.0000000000003262)

Roesch DM, Tian Y, Zheng W, Shi M, Verbalis JG \& Sandberg K 2000 Estradiol attenuates angiotensin-induced aldosterone secretion in ovariectomized rats. Endocrinology 141 4629-4636. (https://doi. org/10.1210/endo.141.12.7822)

Rutkowska-Zapala M, Suski M, Szatanek R, Lenart M, Weglarczyk K, Olszanecki R, Grodzicki T, Strach M, Gasowski J \& Siedlar M 2015 Human monocyte subsets exhibit divergent angiotensin I-converting activity. Clinical and Experimental Immunology 181 126-132. (https:// doi.org/10.1111/cei.12612)

Sai S, Esteves CL, Kelly V, Michailidou Z, Anderson K, Coll AP, Nakagawa Y, Ohzeki T, Seckl JR \& Chapman KE 2008 Glucocorticoid regulation of the promoter of $11 \beta$-hydroxysteroid dehydrogenase type 1 is indirect and requires C/EBP $\beta$. Molecular Endocrinology 22 2049-2060. (https://doi.org/10.1210/me.2007-0489)

Sandhu MS \& Casale TB 2010 The role of vitamin D in asthma. Annals of Allergy, Asthma and Immunology 105 191-199; quiz 200-202, 217. (https://doi.org/10.1016/j.anai.2010.01.013)

Sardu C, Gambardella J, Morelli MB, Wang X, Marfella R \& Santulli G 2020 Hypertension, thrombosis, kidney failure, and diabetes: is COVID-19 an endothelial disease? A comprehensive evaluation of clinical and basic evidence. Journal of Clinical Medicine 91417. (https://doi.org/10.3390/jcm9051417)

Saruta T 1996 Mechanism of glucocorticoid-induced hypertension. Hypertension Research 19 1-8. (https://doi.org/10.1291/hypres.19.1)

Seely EW, Walsh BW, Gerhard MD \& Williams GH 1999 Estradiol with or without progesterone and ambulatory blood pressure in postmenopausal women. Hypertension 33 1190-1194. (https://doi. org/10.1161/01.hyp.33.5.1190)

Senchenkova EY, Russell J, Almeida-Paula LD, Harding JW \& Granger DN 2010 Angiotensin II-mediated microvascular thrombosis. Hypertension 56 1089-1095. (https://doi.org/10.1161/ HYPERTENSIONAHA.110.158220)

Shen JZ, Morgan J, Tesch GH, Rickard AJ, Chrissobolis S, Drummond GR, Fuller PJ \& Young MJ 2016 Cardiac tissue injury and remodeling is dependent upon MR regulation of activation pathways in cardiac tissue macrophages. Endocrinology 157 3213-3223. (https://doi. org/10.1210/en.2016-1040)

Shoemaker R, Yiannikouris F, Thatcher S \& Cassis L 2015 ACE2 deficiency reduces beta-cell mass and impairs beta-cell proliferation in obese C57BL/6 mice. American Journal of Physiology: Endocrinology and Metabolism 309 E621-E631. (https://doi.org/10.1152/ ajpendo.00054.2015)

Shoemaker R, Tannock LR, Su W, Gong M, Gurley SB, Thatcher SE, Yiannikouris F, Ensor CM \& Cassis LA 2019 Adipocyte deficiency of ACE2 increases systolic blood pressures of obese female C57BL/6 mice. Biology of Sex Differences 10 45. (https://doi.org/10.1186/s13293019-0260-8)

Solanki P, Gwini SM, Doery JCG, Choy KW, Shen J, Young MJ, Fuller PJ \& Yang J 2020 Age- and sex-specific reference ranges are needed for the aldosterone/renin ratio. Clinical Endocrinology 93 221-228. (https:// doi.org/10.1111/cen.14199)

Speirs RS, Simpson SA \& Tait JF 1954 Certain biological activities of crystalline electrocortin. Endocrinology 55 233-236. (https://doi. org/10.1210/endo-55-2-233)
Sun JY, Li C, Shen ZX, Zhang WC, Ai TJ, Du LJ, Zhang LJ, Yao YY, Liu GF, Sun Y, et al. 2016 Mineralocorticoid receptor deficiency in macrophages inhibits neointimal hyperplasia and suppresses macrophage inflammation through SGK1-AP1/NF-kappabeta pathways. Arteriosclerosis, Thrombosis, and Vascular Biology 36 874-885.

Sunden-Cullberg J, Nilsson A \& Inghammar M 2020 Sex-based differences in ED management of critically ill patients with sepsis: a nationwide cohort study. Intensive Care Medicine 46 727-736. (https://doi. org/10.1007/s00134-019-05910-9)

Swärd P, Edsfeldt A, Reepalu A, Jehpsson L, Rosengren BE \& Karlsson MK 2020 Age and sex differences in soluble ACE2 may give insights for COVID-19. Critical Care 24 221. (https://doi.org/10.1186/s13054-02002942-2)

Tai W, He L, Zhang X, Pu J, Voronin D, Jiang S, Zhou Y \& Du L 2020 Characterization of the receptor-binding domain (RBD) of 2019 novel coronavirus: implication for development of RBD protein as a viral attachment inhibitor and vaccine. Cellular and Molecular Immunology 17 613-620. (https://doi.org/10.1038/s41423-020-0400-4)

Tang BM, Craig JC, Eslick GD, Seppelt I \& Mclean AS 2009 Use of corticosteroids in acute lung injury and acute respiratory distress syndrome: a systematic review and meta-analysis. Critical Care Medicine 37 1594-1603. (https://doi.org/10.1097/ CCM.0b013e31819fb507)

Tang N, Bai H, Chen X, Gong J, Li D \& Sun Z 2020 Anticoagulant treatment is associated with decreased mortality in severe coronavirus disease 2019 patients with coagulopathy. Journal of Thrombosis and Haemostasis 18 1094-1099. (https://doi.org/10.1111/ jth.14817)

Tersalvi G, Vicenzi M, Calabretta D, Biasco L, Pedrazzini G \& Winterton D 2020 Elevated troponin in patients with coronavirus disease 2019: possible mechanisms. Journal of Cardiac Failure 26 470-475. (https:// doi.org/10.1016/j.cardfail.2020.04.009)

Teuwen LA, Geldhof V, Pasut A \& Carmeliet P 2020 COVID-19: the vasculature unleashed. Nature Reviews: Immunology 20 389-391. (https://doi.org/10.1038/s41577-020-0343-0)

Thompson BT 2003 Glucocorticoids and acute lung injury. Critical Care Medicine 31 (Supplement) S253-S257. (https://doi.org/10.1097/01. CCM.0000057900.19201.55)

Tipnis SR, Hooper NM, Hyde R, Karran E, Christie G \& Turner AJ 2000 A human homolog of angiotensin-converting enzyme. Cloning and functional expression as a captopril-insensitive carboxypeptidase. Journal of Biological Chemistry 275 33238-33243. (https://doi. org/10.1074/jbc.M002615200)

Usher MG, Duan SZ, Ivaschenko CY, Frieler RA, Berger S, Schutz G, Lumeng CN \& Mortensen RM 2010 Myeloid mineralocorticoid receptor controls macrophage polarization and cardiovascular hypertrophy and remodeling in mice. Journal of Clinical Investigation 120 3350-3364. (https://doi.org/10.1172/JCI41080)

Van Den Berghe G, Boonen E \& Walker BR 2013 Reduced cortisol metabolism during critical illness. New England Journal of Medicine 369 481. (https://doi.org/10.1056/NEJMc1306703)

Vandermosten L, De Geest C, Knoops S, Thijs G, Chapman KE, De Bosscher K, Opdenakker G \& Van Den Steen PE 2017 11Betahydroxysteroid dehydrogenase type 1 has no effect on survival during experimental malaria but affects parasitemia in a parasite strainspecific manner. Scientific Reports 7 13835. (https://doi.org/10.1038/ s41598-017-14288-x)

Vandermosten L, Pham TT, Knoops S, De Geest C, Lays N, Van Der Molen K, Kenyon CJ, Verma M, Chapman KE, Schuit F, et al. 2018 Adrenal hormones mediate disease tolerance in malaria. Nature Communications 9 4525. (https://doi.org/10.1038/s41467-018-06986-5)

Vasanthakumar A, Chisanga D, Blume J, Gloury R, Britt K, Henstridge DC, Zhan Y, Torres SV, Liene S, Collins N, et al. 2020 Sex-specific adipose tissue imprinting of regulatory T cells. Nature 579 581-585. (https://doi.org/10.1038/s41586-020-2040-3) https://joe.bioscientifica.com https://doi.org/10.1530/JOE-20-0260 (c) 2020 Society for Endocrinology Published by Bioscientifica Ltd. Printed in Great Britain 
Verdecchia P, Cavallini C, Spanevello A \& Angeli F 2020 The pivotal link between ACE2 deficiency and SARS-CoV-2 infection. European Journal of Internal Medicine 76 14-20. (https://doi.org/10.1016/j.ejim.2020.04.037)

Verdoni L, Mazza A, Gervasoni A, Martelli L, Ruggeri M, Ciuffreda M, Bonanomi E \& D'antiga L 2020 An outbreak of severe Kawasakilike disease at the Italian epicentre of the SARS-CoV-2 epidemic: an observational cohort study. Lancet 395 1771-1778. (https://doi. org/10.1016/S0140-6736(20)31103-X)

Verma M, Kipari TMJ, Zhang Z, Man TY, Forster T, Homer NZM, Seckl JR, Holmes MC \& Chapman KE 2018 11beta-Hydroxysteroid dehydrogenase-1 deficiency alters brain energy metabolism in acute systemic inflammation. Brain, Behavior, and Immunity 69 223-234. (https://doi.org/10.1016/j.bbi.2017.11.015)

Vettorazzi S, Bode C, Dejager L, Frappart L, Shelest E, Klassen C, Tasdogan A, Reichardt HM, Libert C, Schneider M, et al. 2015 Glucocorticoids limit acute lung inflammation in concert with inflammatory stimuli by induction of SphK1. Nature Communications 6 7796. (https://doi.org/10.1038/ncomms8796)

Wepler M, Preuss JM, Merz T, Hartmann C, Wachter U, Mccook O, Vogt J, Kress S, Groger M, Fink M, et al. 2019 Impaired glucocorticoid receptor dimerization aggravates LPS-induced circulatory and pulmonary dysfunction. Frontiers in Immunology 10 3152. (https://doi. org/10.3389/fimmu.2019.03152)

White WB, Hanes V, Chauhan V \& Pitt B 2006 Effects of a new hormone therapy, drospirenone and 17-beta-estradiol, in postmenopausal women with hypertension. Hypertension 48 246-253. (https://doi. org/10.1161/01.HYP.0000232179.60442.84)

Wu YH, Li JY, Wang C, Zhang LM \& Qiao H 2017 The ACE2 G8790A polymorphism: involvement in type 2 diabetes mellitus combined with cerebral stroke. Journal of Clinical Laboratory Analysis 31 e22033. (https://doi.org/10.1002/jcla.22033)

Wust S, Tischner D, John M, Tuckermann JP, Menzfeld C, Hanisch UK, Van Den Brandt J, Lühder F \& Reichardt HM 2009 Therapeutic and adverse effects of a non-steroidal glucocorticoid receptor ligand in mouse model of multiple sclerosis. PLoS ONE 4 e8202. (https://doi. org/10.1371/journal.pone.0008202)
Xu J, Yang J, Chen J, Luo Q, Zhang Q \& Zhang H 2017 Vitamin D alleviates lipopolysaccharideinduced acute lung injury via regulation of the reninangiotensin system. Molecular Medicine Reports 16 7432-7438. (https://doi.org/10.3892/mmr.2017.7546)

Yang Y, Du H, Li Y, Guan W, Tang F, Ga Q \& Ge RL 2019 NR3C1 gene polymorphisms are associated with high-altitude pulmonary edema in Han Chinese. Journal of Physiological Anthropology 38 4. (https://doi. org/10.1186/s40101-019-0194-1)

Young MJ 2013 Targeting the mineralocorticoid receptor in cardiovascular disease. Expert Opinion on Therapeutic Targets 17 321-331. (https://doi.org/10.1517/14728222.2013.748750)

Zhang Y, Li H, Zhang J, Cao Y, Zhao X, Yu N, Gao Y, MA, Zhang J, Zhang H, Guo J, et al. 2020 The clinical characteristics and outcomes of diabetes mellitus and secondary hyperglycaemia patients with coronavirus disease 2019: a single-center, retrospective, observational study in Wuhan. Diabetes, Obesity and Metabolism 22 1443-1454.

Zhao Z, Wang H, Jessup JA, Lindsey SH, Chappell MC \& Groban L 2014 Role of estrogen in diastolic dysfunction. American Journal of Physiology: Heart and Circulatory Physiology 306 H628-H640. (https:// doi.org/10.1152/ajpheart.00859.2013)

Zhao X, Guo F, Comunale MA, Mehta A, Sehgal M, Jain P, Cuconati A, Lin H, Block TM, Chang J, et al. 2015 Inhibition of endoplasmic reticulum-resident glucosidases impairs severe acute respiratory syndrome coronavirus and human coronavirus NL63 spike proteinmediated entry by altering the glycan processing of angiotensin I-converting enzyme 2. Antimicrobial Agents and Chemotherapy 59 206-216. (https://doi.org/10.1128/AAC.03999-14)

Zhou C, Lu F, Cao K, Xu D, Goltzman D \& Miao D 2008 Calciumindependent and 1,25(OH)2D3-dependent regulation of the reninangiotensin system in 1alpha-hydroxylase knockout mice. Kidney International 74 170-179. (https://doi.org/10.1038/ki.2008.101)

Zhu L, She ZG, Cheng X, Qin JJ, Zhang XJ, Cai J, Lei F, Wang H, Xie J, Wang W, et al. 2020 Association of blood glucose control and outcomes in patients with COVID-19 and pre-existing Type 2 diabetes. Cell Metabolism 31 1068.e3-1077.e3. (https://doi. org/10.1016/j.cmet.2020.04.021)

Received in final form 6 July 2020

Accepted 5 August 2020

Accepted Manuscript published online 6 August 2020 (c) 2020 Society for Endocrinology Published by Bioscientifica Ltd. Printed in Great Britain 